\title{
Covariational Reasoning of Prospective Mathematics Teachers: How Do Dynamic Animations Affect?"
}

\author{
Mahmut Kertil \\ ${ }^{\mathrm{a}}$ Marmara University, Atatürk Faculty of Education, İstanbul/Turkey, (ORCID: 0000-0002-0633-7144)
}

Article History: Received: 28 November 2019; Accepted: 6 March 2020; Published online: 11 March 2020

\begin{abstract}
Covariational reasoning is about the ability of coordinating the variation in two simultaneously and dynamically changing quantities and being able to see these quantities at the same time by forming a multiplicative unit. Covariational reasoning ability has been considered as necessary and foundational to the understanding of many mathematical concepts ranging from elementary to tertiary levels. In this study, covariational reasoning abilities of prospective elementary school mathematics teachers and the effects of dynamic animations created in computer-based environments on these abilities have been investigated. Case study was used as a research design one of which is a qualitative research methodology. The participants of the study were 19 prospective elementary school mathematics teachers attending to an elective ComputerAssisted Mathematics Education course and four of them were selected for semi-structured interviews. The results showed the weakness in prospective elementary school mathematics teachers' covariational reasoning abilities and the potential of dynamic animations in supporting covariational reasoning. The animations in dynamic computer environments seem to have minimal effect on paper and pencil solutions in general. However, these animations, if they were used with their data collection and graph drawing properties, affected prospective teachers ways of reasoning in two ways: (i) forcing them to revise and rethink about the current ways of reasoning used during paper and pencil solutions, and (ii) lowering the cognitive load or removing the necessity of deep thinking on the situation. For the first case, the activities supported with the dynamic animations play a supportive role in developing covariational reasoning. For the second case, the dynamic animations did not contribute to prospective teachers' covariational reasoning, rather they just played a mediating tool role that helps them to find a result.
\end{abstract}

Keywords: Change, rate of change, covariation, covariational reasoning, quantitative reasoning

DOI: $10.16949 /$ turkbilmat.652481

Öz: Kovaryasyonel düşünme eş zamanlı ve dinamik olarak değişen iki niceliğin birlikte değişimini düşünerek koordine edebilme ve değişimler arasındaki ilişkiyi bir bütün olarak yorumlayabilme becerisidir. Kovaryasyonel düşünme becerisi oran-orantı, türev ve integral gibi ilköğretim ve daha ileri düzeyde birçok matematiksel kavramın anlaşılmasında önemlidir. $\mathrm{Bu}$ çalışmada, ilköğretim matematik öğretmen adaylarının kovaryasyonel düşünme becerileri ve bilgisayar destekli ortamlarında oluşturulan dinamik animasyonların bu becerileri nasıl etkilediği incelenmiştir. Nitel araştırma yöntemlerinden özel durum çalışması kullanılmıştır. Çalışmanın katılımcıları, Bilgisayar Destekli Matematik Öğretimi dersine kayıtlı son sınıf 19 ilköğretim matematik öğretmen adayı olup dört öğretmen adayı ile yarı-yapılandırılmış görüşmeler yapılmıştır. Elde edilen bulgular öğretmen adaylarının kovaryasyonel düşünme becerilerinin yeterli düzeyde olmadığını ve dinamik geometri yazılımları ile elde edilen animasyonların kovaryasyonel düşünme becerisine katkı sağlayabileceğini göstermektedir. Sadece dinamik animasyon oluşturmanın ve onu izlemenin öğretmen adaylarının kâğıt-kalem çözümlerine etkisi çok azdır. Fakat animasyonlar, dinamik geometri programının veri alma ve grafik çizdirme özellikleri ile birlikte kullanıldığında, ögretmen adaylarının kovaryasyonel düşünme becerilerini iki şekilde etkilemiştir: (i) statik (kâğıt-kalem) bağlamlardaki düşünme biçimlerinden farklı sonuçlar vererek tekrar düşünmeye sevk etme veya (ii) zihinsel iş yükünü alarak durum üzerinde derin düşünme gereksinimini ortadan kaldırma. Birinci durumda dinamik animasyonlar öğretmen adayları için kovaryasyonel düşünmeyi destekleyici bir unsur olurken ikinci durumda ise çözüme odaklı ve durum üzerinde derinlemesine düşünme ihtiyacını ortadan kaldıran bir araç rolünü almıştır.

Anahtar Kelimeler: Değişim, değişim oranı, kovaryasyon, kovaryasyonel düşünme, niceliksel düşünme

Türkçe sürüm için tıklayınız

\section{Introduction}

Change, variation, and covariation of quantities are foundational for many of the mathematical concepts (Confrey \& Smith, 1994; Thompson, 1994). Reasoning on the simultaneous and dynamic variation between quantities have been generally investigated under the theoretical construct of covariational reasoning (Carlson, Jacobs, Coe, Larsen \& Hsu, 2002; Johnson, 2012; Saldanha \& Thompson, 1998; Thompson \& Carlson, 2017). According to Carlson et al. (2002), covariational reasoning involves the mental actions used in the process of coordinating the variation in simultaneously changing quantities. These mental actions were developmentally classified at different levels from person to person. Thompson and Carlson (2017), on the other hand, described the high level of covariational reasoning as the ability to construct a multiplicative object as a result of uniting

Corresponding Author: Mahmut Kertil (D) email: mkertil@marmara.edu.tr

*This article is the extended version of the paper presented in $4^{\text {th }}$ International Symposium of Turkish Computer and Mathematics Education. Citation Information: Kertil, M. (2020). Covariational reasoning of prospective mathematics teachers: How do dynamic animations affect? Turkish Journal of Computer and Mathematics Education, 11(2), 312-342. 
the measured properties of simultaneously changing quantities by which one can see the system as a whole (e.g. quantity1, quantity2, qunatity1-quantity2). As an example, for a tank filled by water, the volume of water and the height of water in the tank are two simultaneously and dynamically changing quantities. Forming a new multiplicative object is related to the ability to mentally uniting the variation in both quantities jointly and separately as a whole structure (e.g., volume, height, volume-height).

Covariational reasoning is a theoretical construct which focuses on ways of thinking such as being able to coordinate the changes in one quantity as happening simultaneously with changes in the other quantity or not; focusing on the changes in only one quantity or changes in two quantities at the same time; focusing the intensity of changes in two quantities separately or focusing on the rate of change between two (Carlson et al., 2002; Thompson \& Carlson, 2017). According to Thompson and Carlson (2017), covariational reasoning is developmental, and students can be labeled at different levels in terms of having this ability. Covariational reasoning is foundational for the understanding of many mathematical concepts. Some studies indicated that one of the main reasons of student and teacher difficulties with the concepts of ratio, proportion, function, rate of change, derivative, and integration may be related to their lack of covariational reasoning (Carlson, 1998; Carlson et al., 2002; Kertil, 2014; Monk, 1992; Thompson, 1994). For the concept of function, for example, the widespread use of the correspondence approach in teaching seems to be an inhibiter for students in developing the idea of dynamic and simultaneous changes in variables (Carlson, 1998; Confrey \& Smith, 1994; Oehrtman, Carlson \& Thompson, 2008; Stroup, 2002; Thompson \& Carlson, 2017). The study by Oehrtman and others (2008) showed that teaching functions with an emphasis on the correspondence (input-output) approach resulted in difficulties for conceptualizing this concept as a dynamic covariation between variables. Because covariational reasoning involves reasoning on dynamic and simultaneous changes in quantities, having this ability may contribute students in conceptualizing the function concept in a better way (Carlson et al., 2002; Monk, 1992; Thompson \& Carlson, 2017).

Accordingly, student and teacher difficulties with ratio and proportion concepts seem to be related to their lack of covariational reasoning (e.g., Herbert \& Pierce, 2011, 2012; Lobato \& Ellis, 2010). When students were asked about the velocity of a car or a moving object, they can answer just looking at the time variable (Lobato \& Thanheiser, 2002). Moreover, the teaching of ratio and proportion concepts without emphasizing the covariational reasoning in elementary levels seems to result in misuse of linear relationships in the following grades (De Bock, Van Dooren, Janssens \& Verschaffel, 2002; Monk, 1992). Students tend to think linearly about the contexts involving simultaneously changing quantities even if they don't have a constant rate of change. Because students having a high level of covariational reasoning can focus on the changes in covarying quantities separately and together, they can easily distinguish between the linear and non-linear relationships as well as they can express verbally and show on the graph (Castillo-Garsow, 2012; Stroup, 2002; Thompson, Hatfield, Yoon, Joshua \& Byerley, 2017).

According to Thompson and others (2017), as the grade levels increase, the covariational reasoning of students does not necessarily develop. Even students at higher levels may have more difficulty in covariational reasoning when compared to younger students, and they are not open developing the capacity to create multiplicative objects (Thompson et al., 2017). According to Thompson and others (2017), this may be the expected result of the common school practices and teaching methods of mathematical concepts without an emphasis on covariational reasoning that students encounter throughout their school life. Therefore, covariational reasoning should be considered in the teaching of mathematical concepts from early grades on.

Some studies conducted in Turkey also shows student and teacher difficulties with covariational reasoning (Kertil, Erbaş \& Çetinkaya, 2019; Yemen-Karpuzcu, Ulusoy \& Işıksal-Bostan, 2017; Şen-Zeytun, Çetinkaya \& Erbaş, 2010). As being foundational for conceptual understanding of many mathematical concepts, it seems necessary for teachers to have an awareness and ability of covariational reasoning as a part of their professional knowledge. Many studies also indicated the need for further studies and interventions in emphasizing and developing covariational reasoning of students at all levels of schooling as well as pre-service and in-service mathematics teachers (Ärlebäck, Doerr \& O’Neil, 2013; Carlson et al., 2002; Carlson, Larsen \& Lesh, 2003; Thompson \& Carlson, 2017; Thompson et al., 2017). Some studies showed the potential of computer-based dynamic learning environments in supporting students' covariational reasoning and conceptualizing important mathematical ideas such as functions (e.g., Hoffkamp, 2011; Johnson, McClintock \& Hornbein, 2017). However, more studies have been suggested on this topic in different contexts (Johnson et al., 2017; Thompson et al., 2017). The purpose of this study is to investigate the covariational reasoning of elementary school prospective mathematics teachers in a series of modeling activities, and the potential effects of computer-based dynamic animations on their reasoning. Although the covariational reasoning of prospective teachers was not investigated for a special mathematical concept, the activities used in the study include function, graphs of functions, and rate of change concepts. The research questions guiding the study are:

i. How does the covariational reasoning of prospective elementary school mathematics teachers appear in their solution of mathematical modeling activities? 
ii. How is the covariational reasoning of prospective teachers affected when the task contexts are reintroduced via computer-based dynamic animations?

\subsection{Conceptual Framework}

Carlson and others (2002) introduced the first analytical framework for characterizing students' covariational reasoning which involves five levels according to the mental actions used. According to the description of Carlson and others (2002, s.358), there are five developmental and distinct levels of covariational reasoning which are (i) coordination, (ii) direction, (iii) quantitative coordination, (iv) average rate, and (v) instantaneous rate. These levels of covariational reasoning have been described according to the appearance of certain mental actions, and students are labeled at one of these levels depending on the mental actions they demonstrated. Although this framework has been commonly used as an analytical tool, some studies reported its weaknesses in describing and labeling the diversity in students' thinking (e.g., Ärlebäck et al., 2013; Carlson et al., 2002, 2003; Castillo-Garsow, 2012).

In a recent study, Thompson and Carlson (2017) modified the aforementioned framework, and they determined six major levels of covariational reasoning; (i) no coordination, (ii) pre-coordination, (iii) gross coordination of values, (iv) coordination of values, (v) chunky continuous covariation, and (vi) smooth continuous covariation (p. 441). These levels have been determined depending on the research findings focusing on students' different ways of thinking about the quantities changing together. For instance, chunky continuous covariation and smooth continuous covariation are the concepts first introduced in the context of a study investigating students' quantitative reasoning on exponential functions by Castillo-Garsow (2012). CastilloGarsow (2012) showed that having the ability to smooth continuous covariational reasoning is critical for students to comprehend nonlinear situations involving exponentially changing quantities.

Chunky continuous covariational reasoning appears as attending to the discrete changes and chunks in variables, while smooth continuous covariation entails dynamic and continuous coordination of changes in quantities. For a car moving at a speed of $100 \mathrm{~km} / \mathrm{h}$, considering the changes in the distance only for exact times or whole hours (i.e., 200km in 2 hours) is an example for a chunky way of thinking. For the same car, smooth continuous covariational reasoning requires imagining both time and distance variables changing simultaneously and smoothly through the intervals as small as one wish (i.e., for every 1 minute, for every 1 second), and being aware of the same speed for each interval.

Table 1. Covariational reasoning: Dimensions and sub-dimensions (Kertil et al., 2019)

\begin{tabular}{|c|c|}
\hline Dimensions and Sub-dimensions & Explanation \\
\hline Identifying the variables & \\
\hline Thinking by primary variables & $\begin{array}{l}\text { Values of simultaneously changing quantities explicitly conceived in relation to } \\
\text { each other as dependent and independent variables }\end{array}$ \\
\hline Thinking by secondary variables & Invoking a new variable which is not mentioned in the problem context \\
\hline Reversing the roles of variables & The roles of dependent and independent variables are reversed. \\
\hline
\end{tabular}

2. Ways of coordinating the variables

Uncoordinated way of thinking Considering the changes in covarying quantities as separately with respect to a common variable (e.g., volume increases with respect to time, and height increases with respect to time).

Indirect coordination $\quad$ Indirectly coordination the changes in covarying quantities depending on a third variable (e.g., both volume and height are increasing with respect to time)

Direct coordination

Directly coordinating the changes in covarying quantities without focusing on the intensity (e.g., height increases as the volume increases).

Direct and systematic coordination Directly and systematically coordinating the changes in covarying quantities. Being able to change one of the quantities with equal increments, and observing the simultaneous change in the other quantity (e.g., change in height increases with the per unit change in volume)

\section{Quantifying the rate of change} Gross quantification

Perceptually deciding the rate of change without a mathematical justification; providing incorrect or inconsistent explanations for the concavity on graphs (e.g., the increase in height is gradually slowing down).

Extensive quantification Focusing on the successive changes in only one quantity; additively comparing the successive changes in the dependent variable, while keeping constant the changes in the independent variable (e.g., the change in height gets bigger for every equal amount of change in volume)

Intensive quantification Uniformly changing the input variable (being aware that the unit can be selected as small as possible) and observing the simultaneous change in the independent variable; multiplicatively comparing the changes in quantities; Being able to form a multiplicative object while observing the quantities change together (e.g., the height increases at a decreasing rate with respect to volume) 
The conceptual framework used in this study is the dimensions of covariational reasoning described by Kertil and others (2019). Based on the theory of quantitative reasoning (Thompson, 1994) and by fleshing out the framework introduced by Thompson and Carlson (2017), Kertil and others (2019) proposed a three dimensional perspective for characterizing covariational reasoning; (i) identifying the variables, (ii) coordinating the variables, and (iii) quantifying the rate of change. Table 1 above shows the subcomponents of each dimension with an explanation for the possible ways of reasoning. Although the examples for each dimension and subcomponents in Table 1 are provided in verbal expressions, the descriptions for each way of reasoning has been formed only after they are justified or supported by algebraic and other forms of mathematical representations.

\section{Method}

As one of the qualitative research methodologies, the case study was employed in this study which includes the in-depth analysis of a person, a group, or an event within its phenomenological bounds (Yıldırım \& Şimşek, 2011). The unit of analysis focused on during the study was prospective mathematics teachers' covariational reasoning abilities that they demonstrated in their written solutions and the effects of dynamic animations while solving the modeling activities involving simultaneously and dynamically changing quantities.

\subsection{Participants}

The participants of the current study were 19 (12 female, 7 male) senior year elementary school prospective mathematics teachers attending to a public university and enrolled in an elective Computer-Assisted Mathematics Education course. 19 elementary school prospective teachers regularly continued the course throughout the semester. However, as can be seen in Table 2, only 14 of the participants attended the class during the week of the Water Tank activity. For the other activities, regularly 19 participants attended the class.

At the time of the data collection, most of the participants had completed mathematics courses such as General Mathematics, Calculus-1, Calculus-2, Analytical Geometry, Linear Algebra and some more courses about mathematics education which were offered as part of the program. We assumed that all of the participants were from similar backgrounds in terms of their previous experience with modeling tasks and their subjectmatter knowledge required for solving the tasks.

\subsection{Implementation and Data Collection}

The data collection tools were Water Tank, Sliding Ladder and Space Shuttle modeling activities taken from the study of Kertil (2014) (see Appendix-1). In Water Tank activity, it was asked how volume and height variables change together; in Sliding Ladder activity, it was asked about the covariation of vertical height and horizontal height; in Space Shuttle activity, it was asked about the covariation of the angle of camera and height of the shuttle. Although the activities used in the study were not carrying out all the properties of a good modeling activity described by Lesh and others (2000), they commonly carry out reality, reusability, and simplicity principles, we called them as modeling activities.

At first, participants solved the activities individually by using paper and pencil. For individual (paper and pencil) solutions, thirty minutes were devoted to each activity. After collecting the paper and pencil solution papers, prospective teachers were asked to study on the same tasks by constructing the dynamic animations of the given situations using the appropriate software. Later on, they were asked to write a reflection paper report on how they revised their solutions or their way of reasoning changed after observing the dynamic animations with their property of providing immediate data. Prospective teachers generally used Geogebra or Geometry Sketchpad for constructing the animations of Sliding Ladder and Space Shuttle activities, while they benefited from the www.teachers.desmos.com/waterline interactive learning portal for the Water Tank activity. Prospective teachers decided themselves according to their competence which software program to use for Sliding Ladder and Space Shuttle activities. For the Water Tank activity, on the other hand, because it enables to create different tank shapes, we guided them to use teacher.desmos.com. Prospective teachers were having the necessary competency about each program because, in previous weeks, we executed similar practices like constructing various animations about different mathematical concepts as a regular content of the course. The implementation of Water Tank, Sliding Ladder, and Space Shuttle activities has lasted three weeks. The paper and pencil solutions of the three activities followed by the construction and analysis of the dynamic animations were implemented as a regular part of the course during the $10^{\text {th }}, 11^{\text {th }}$ and $12^{\text {th }}$ weeks of the semester.

After the implementation, task-based interviews were executed with four prospective mathematics teachers. The interviews aimed to get an in-depth understanding of prospective mathematics teachers' ways of covariational reasoning that they demonstrated with paper and pencil solutions. The interviewees were selected considering the criteria of demonstrating the most typical ways of reasoning, having a high level of socialcommunication skills, and being voluntary. 


\subsection{Data Analysis}

The data were analyzed according to the framework introduced in Table 1 by using the constant comparative method (Strauss \& Corbin, 1998). At first, prospective mathematics teachers' solution papers, for each of three activities, were analyzed. We considered the chronological order of the activities while analyzing the paper and pencil solutions. Next, prospective teachers' updated solutions after working with the dynamic computer environment and their reflection papers were analyzed. The descriptive data obtained as a result of these analyses were presented in a table to demonstrate the general state or level of the class. Later, we executed an in-depth analysis of the transcribed interviews conducted with four prospective mathematics teachers. In the findings, we provided some typical excerpts from the interviews for showing the diversity in prospective teachers' ways of thinking.

\section{Findings}

In this part, we first started by presenting the descriptive data about prospective mathematics teachers' covariational reasoning in a table showing the general state of all participants. Prospective mathematics teachers' covariational in their paper and pencil solutions and supported by dynamic animations have been analyzed by using the three-dimensional framework and then, a frequency distribution table has been constructed (see Table 2).

Table 2. Covariational reasoning of prospective mathematics teachers demonstrated in their paper and pencil solutions versus in their solutions supported with dynamic animations

\begin{tabular}{|c|c|c|c|c|c|c|c|}
\hline \multirow{2}{*}{\multicolumn{2}{|c|}{$\begin{array}{c}\text { Covariational Reasoning } \\
\text { Dimensions and Sub-dimensions }\end{array}$}} & \multicolumn{3}{|c|}{ Paper and Pencil } & \multicolumn{3}{|c|}{$\begin{array}{c}\text { Supported with Dynamic } \\
\text { Animations }\end{array}$} \\
\hline & & \multirow{3}{*}{$\begin{array}{c}\text { Water } \\
\text { Tank } \\
(\mathrm{N}=14)\end{array}$} & \multirow{3}{*}{$\begin{array}{c}\begin{array}{c}\text { Sliding } \\
\text { Ladder } \\
(\mathrm{N}=19)\end{array} \\
12\end{array}$} & $\begin{array}{l}\text { Space } \\
\text { Shuttle } \\
(\mathrm{N}=19)\end{array}$ & \multirow{2}{*}{$\begin{array}{l}\text { Water } \\
\text { Tank } \\
(\mathrm{N}=14)\end{array}$} & \multirow{2}{*}{$\begin{array}{l}\text { Sliding } \\
\text { Ladder } \\
(\mathrm{N}=19)\end{array}$} & \multirow{2}{*}{$\begin{array}{l}\text { Space } \\
\text { Shuttle } \\
(\mathrm{N}=19)\end{array}$} \\
\hline \multirow{3}{*}{$\begin{array}{l}\text { 1. Identifying the } \\
\text { variables }\end{array}$} & & & & & & & \\
\hline & $\begin{array}{l}\text { Thinking by primary } \\
\text { variables }\end{array}$ & & & 10 & 14 & 19 & 16 \\
\hline & $\begin{array}{l}\text { Thinking by secondary } \\
\text { variables }\end{array}$ & 4 & 7 & 7 & 0 & 0 & 1 \\
\hline \multirow{5}{*}{$\begin{array}{l}\text { 2. Coordinating the } \\
\text { variables }\end{array}$} & $\begin{array}{l}\text { Reversing the roles of } \\
\text { variables }\end{array}$ & 2 & 0 & 2 & 0 & 0 & 2 \\
\hline & $\begin{array}{l}\text { Uncoordinated way of } \\
\text { thinking }\end{array}$ & 0 & 2 & 1 & 0 & 0 & 0 \\
\hline & Indirect coordination & 5 & 5 & 5 & 0 & 0 & 0 \\
\hline & Direct coordination & 8 & 12 & 9 & 7 & 10 & 10 \\
\hline & $\begin{array}{l}\text { Direct and systematic } \\
\text { coordination }\end{array}$ & 1 & 0 & 4 & 7 & 8 & 9 \\
\hline \multirow{3}{*}{$\begin{array}{l}\text { 3. Quantifying the } \\
\text { rate of change }\end{array}$} & Gross quantification & 10 & 15 & 11 & 6 & 9 & 10 \\
\hline & Extensive quantification & 4 & 3 & 7 & 5 & 6 & 6 \\
\hline & Intensive quantification & 0 & 1 & 1 & 3 & 3 & 3 \\
\hline
\end{tabular}

For the first dimension of covariational reasoning that of identifying the variables, the frequency of thinking with secondary variables seems high in paper and pencil solution of prospective teachers throughout the three activities. During the works on the same activities by constructing the dynamic animations, the frequency of thinking with secondary variables was considerably decreased. Thinking by reversing the roles of variables rarely appeared during the studies supported by dynamic animations depending on the nature of the activities. Although thinking with secondary variables is not an incorrect way of thinking, it may result in an uncoordinated way of thinking or indirect coordination of variables in the subsequent dimensions of the covariational reasoning. An uncoordinated way of thinking or indirect coordination of variables can be seen as an indicator of a low level of covariational reasoning.

For the second dimension, prospective mathematics teachers frequently used indirect coordination or direct coordination for the simultaneous variation in quantities changing together in their paper and pencil solutions. Indirect coordination of variables seems to be the result of thinking with the secondary variables. Direct and systematic coordination, which is an indicator of the high level of covariational reasoning, was rarely observed in paper and pencil solutions. Moreover, Table 2 shows that, with the use of dynamic animations, prospective teachers' use of uncoordinated way of thinking or indirect coordination decreased, and they frequency demonstrated direct coordination or direct or systematic coordination while coordinating the simultaneously changing quantities. 
For the third dimension, prospective mathematics teachers frequently used gross quantification while quantifying the rate of change in their paper and pencil solutions. The usage of extensive and intensive quantifications while quantifying the rate of change increased when the activities were supported by the dynamic animations. However, still, the gross quantification was the most frequently used way for quantifying the rate of change. In the following parts of the paper, findings related to four prospective mathematics teachers as different cases will be presented providing shreds of evidence from their written solutions and transcribed interviews.

\subsection{Prospective Mathematics Teacher Coded as PST3}

For the Water Tank activity, PST3 thought with primary variables and he could be able to coordinate the variables directly (see Figure 1a). However, he used a gross quantification while quantifying the rate of change as observed in his verbal explanation for the graph. Similarly, concerning Sliding Ladder and Space Shuttle activities, PST3 thought with the primary variables and he directly coordinated the variables (see Figures 1b; 1c). In the solution for Sliding Ladder activity, PST3 used gross quantification for the rate of change as he indicated a linear relationship between the covariation of vertical distance and horizontal distance variables. PST3's preference for using gross quantification can be explained as the result of his inability to use direct and systematic coordination in the previous phase of covariational reasoning.

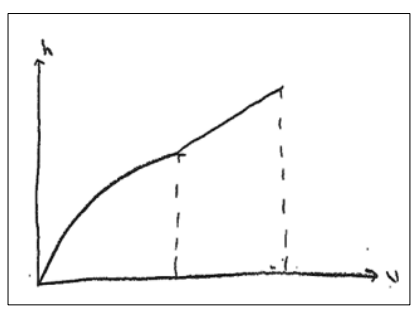

Figure 1a. PST3's paper-pencil graph for Water Tank

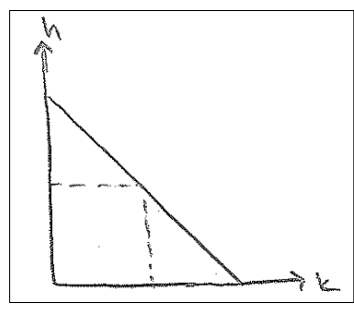

Figure 1b. PST3's paper-pencil graph for Sliding Ladder

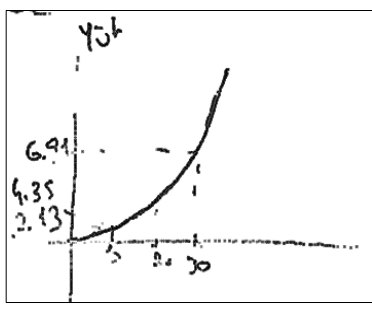

Figure 1c. PST3's paper-pencil graph for Space Shuttle

For the Space Shuttle activity, PST3 thought with the primary variables, he used direct and systematic coordination for the first time, but he quantified the rate of change by using gross quantification. After reworking on the activities with the dynamic animations, his solutions for Water Tank and Space Shuttle activities remained the same while he changed his solution for the Sliding Ladder activity. The following excerpt shows PST3's ways of reasoning related to Sliding Ladder, and how he changed his way of reasoning while working with dynamic animation.

Researcher: In paper and pencil solution, you thought as if there was a linear relationship in Sliding Ladder. Namely, you thought in a way that the amount of increase in horizontal distance was the same with the amount of decrease in height.

PST3: Yes, at first, I thought in that way. But, after reworking on the problem with the dynamic animation, I realized the changes in the variables were not going linear, changes in the variables were related to their squares.

Researcher: Okay. Could you please explain here again your way of reasoning? You can use dynamic animation.

PST3: Of course... We can watch by animating the sliding ladder, the tracking property. Or I can observe the differences between changes. I mean, I can check for how one quantity changed with one unit increment of the other quantity.

Researcher: You already measured some values for height and horizontal distance. Could you please show us now?

PST3: Of course. Now let's start with zero, now the height is at its maximum value, horizontal distance 0,06, height is 6,83. The horizontal distance is 1,04 now and height is 6,75. Let's change it to 2,02, and height is 6,52. When the horizontal distance is 3 , height became 6,13. Now we can relate the amount of decrease in height and the amount of increase in vertical distance.

Researcher: Okay, how?

PST3: Now the horizontal distance increased by 1 unit, height decreased by a 0,08 unit. Repeating this, this increased 1 unit, this decreased by a 0,23 unit. For the next iteration, probably height will decrease more. Yes, it decreased from 6,52 to 6,12 with a 0,40 unit. We can observe that for every one-unit increase in horizontal distance, the amount of decrease in height is gradually increasing. I mean, the amount of decrease is increasing... 


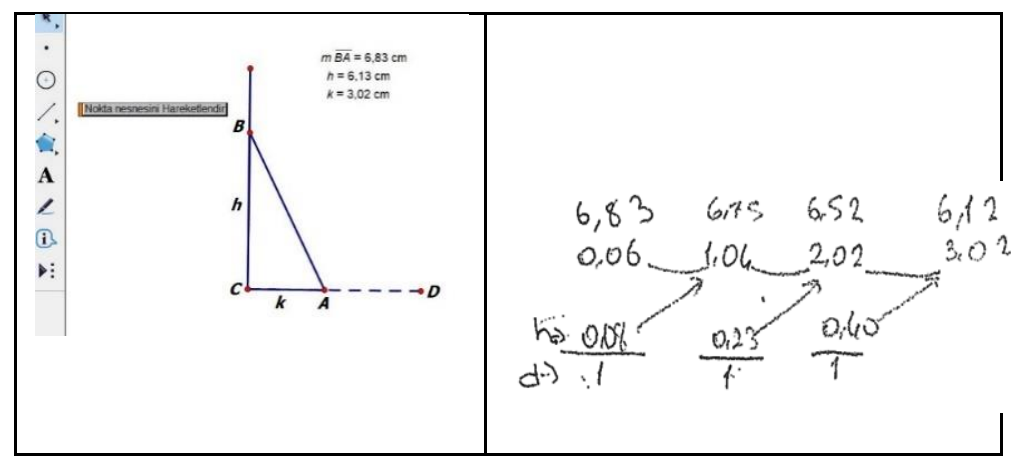

Figure 2. An excerpt from PST3's work with dynamic animation

Researcher: How about the graph?

PST3: [Draws a concave upwards decreasing graph]. Here, $h$ is increasingly decreasing, I mean it is rapidly decreasing while $k$ is increasing constantly. We are keeping the increase in $k$ constant here and observing the change in $h$. We can also do the reverse.

Researcher: Okay, you said this (height) is increasingly decreasing, and this (horizontal distance) is increasing constantly. How are they changing together?

PST3: Hmmm... Indeed, we can also think reversely. I mean, if this is increasingly decreasing, then the other one is increasingly increasing or decreasingly increasing. Sorry, let me think for a while... [He is watching the animation by focusing on the changing values] $h$ is increasingly decreasing, $k$ is increasing constantly. We can also say that if we consider the increase in $k$ with constant increments, then $h$ increasingly decreases.

Researcher: Well, could you please show us the idea that you worked out numerically on the graph? What does that mean on graph?

PST3: [Roughly plotting the numerical values and drawing a concave downwards decreasing graph]. Because I increased $k$ with equal amounts, we should plot the height values at further down points. It would be linear otherwise. I mean, the slope between the subsequent points should gradually increase.

After working with the dynamic animation, PST3 updated his graph for Sliding Ladder activity as a concave downwards decreasing graph. His argumentation for the new graph was the algebraic equation $h^{2}+k^{2}=l^{2}$ where $l$ stands for the length of the ladder. In his paper and pencil solution, although PST3 based his verbal explanations on the $h^{2}+k^{2}=l^{2}$ algebraic equation, he sketched a linear graph without reflecting his ways of covariational reasoning. The dynamic animations forced PST3 to rethink about the situation in detail. As we asked him to explain the graph again during the interview, he used the data collection property of GSP software, and he recorded some numerical values for height and horizontal distance variables. By effectively using the direct and systematics coordination, PST3 changed the horizontal distance with one unit increments and observed the rapid decrease in the height. PST3 extensively quantified the rate of change because he consistently focused on the variation in only one of the quantities (i.e., height is increasingly decreasing) while explaining the concavity of the graph. The data collection property of a dynamic animation environment helped PST3 to use direct and systematic coordination. Moreover, it also provided PST3 to be able to quantify the rate of change by using extensive quantification. In the episode below, PST3 indicated his ideas about the use of dynamic animations.

Researcher: All right, why did you think as if there was a linear relationship before?

PST3: Yes, in fact, when I found h square plus $k$ square equals $l$ square, I felt it was so simple and I didn't need to think in-depth about it. It seemed so easy for me. There was no need to think about it.

Researcher: Well, what did constructing the animation and working with it provide you?

PST3: The animation itself did not, but the data that we collected using it helped us to clarify our thoughts. For example, we always use the formula a square plus $b$ square equal to $c$ square $\left(a^{2}+b^{2}=c^{2}\right)$ in the lessons, but we don't think about it very much. But we can observe the instantaneous values of $a$, $b$, and $c$ quantities instantaneously and simultaneously as they change together. I mean, students also may fall into error as I did here, something like "this decreases by 1 unit, the other increases by 1 unit". Because we can see the instantaneous values of each variable within the dynamic animation, it is easier to realize the inequality of the changes.

Researcher: Did you mean the benefit of dynamic animation?

PST3: Definitely, as I said before students can develop more accurate ideas about the relation between the variables as they can see the instantaneous values of each variable as they change simultaneously.

Researcher: What about teaching in static nature with paper and pencil?

PST3: Of course maybe, but we will try to imagine in our mind what we directly observe dynamically here... I mean, we can get infinitely many data in here while we can work on a few values with paper and pencil. And also, we can get some radical numbers as result in paper and pencil solutions, as I did, which makes it more difficult to think with. But within such software, we can see the data with all intermediate values holistically which helps students to think effectively. 
In the episode given above, by emphasizing its data collection and analysis properties, PST3 indicated that the dynamic geometry software helped him to realize explicitly the relationship between the numerical values of the variables that appeared in the algebraic expression of Pythagorean Theorem. As indicated by PST3, although some numerical values can be worked out by paper and pencil, its limitation is clear when compared to the opportunity provided by dynamic geometry software. Because PST3 could be able to use the quantitative operations more efficiently by utilizing the data collection property of dynamic animation, he could be able to get more proper decisions about the covariation of quantities. In Space Shuttle activity, on the other hand, PST3' paper-pencil solution did not change after working with the dynamic animation. But, PST3 indicated again that dynamic animation in the Space Shuttle context also provided him to realize the covariation in terms of the numerical values.

\subsection{Prospective Mathematics Teacher Coded as PST4}

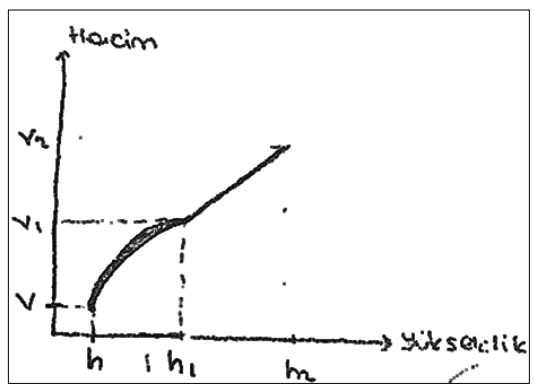

Figure 3a. PST4's paper-pencil solution for Water Tank activity

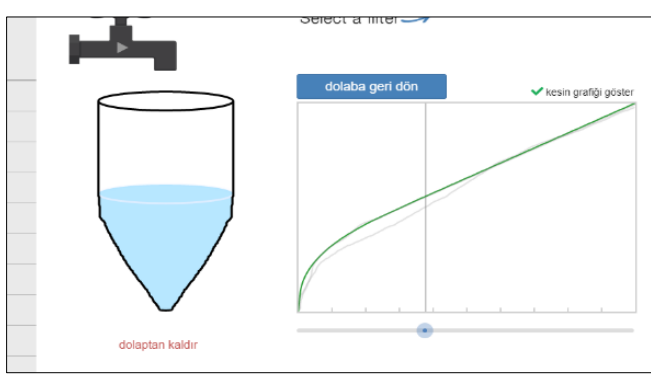

Figure 3b. An excerpt from PST4's work with dynamic animation

When the paper-pencil solution of PST4 (one of the interviewees) was analyzed, she thought with the primary variables but reversing their roles as can be seen in Figure 3a and Figure 3b. Although PST4 plotted height as the independent variable and volume as the dependent variable on the axes of the graph, she indicated "height as a function of volume" in her verbal explanations, and also she drew the graph following this idea. PST4's way of thinking by reversing the roles of variables resulted in an inconsistency between the verbal expression and graphical representation he used. Studying with the dynamic animation, she obtained the above graph (see, Figure 3b). PST4 indicated the similarity between her paper-pencil graph and the graph obtained with the computer-based environment, but she surprised by the absence of the sharp corner on the dynamic graph. As most of the participants also did, the sharp corner on the graph drawn by PST4 has been interpreted as an indicator of her difficulty in attending to quantify the rate of change by intensive quantification.

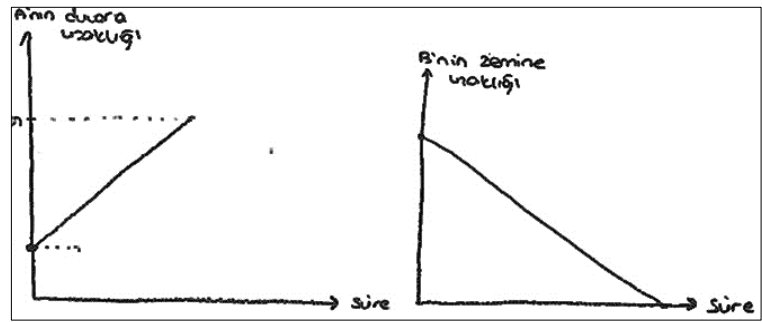

Figure 4a. PST4's paper-pencil graph for Sliding Ladder

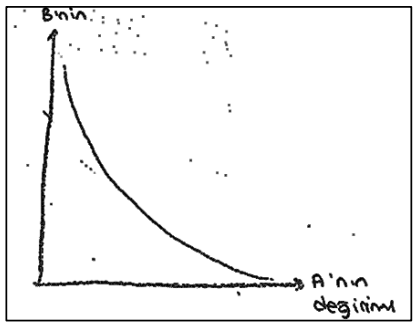

Figure 4b. PST4 revised her graph after seeing the dynamic animation

For Sliding Ladder activity, PST4 thought with a secondary variable that of time. She sketched two graphs one for showing the distance of point A from the Wall as a function of time, and the other graph for the distance of point B to the ground as a function of time (see Figure 4a). This is a typical example of an uncoordinated way of thinking. PST4, in the beginning, could not form a direct relationship between the covarying quantities, instead, she used the time variable. She also used gross quantification for quantifying the rate of change as she used linear graphs without focusing on the intensity of changes.

After collecting the paper and pencil solution papers, PST4 constructed a dynamic animation of the sliding ladder using GSP software as can be seen in Figure 5a. After constructing this animation, PST4 wanted to revise her paper-pencil graphs and, she updated the graph showing the nonlinear relationship between height and horizontal distance variables as seen in Figure $4 \mathrm{~b}$. With the revised graph, PST4 removed the time variable, started to think with primary variables, and so she directly coordinated the variables. 


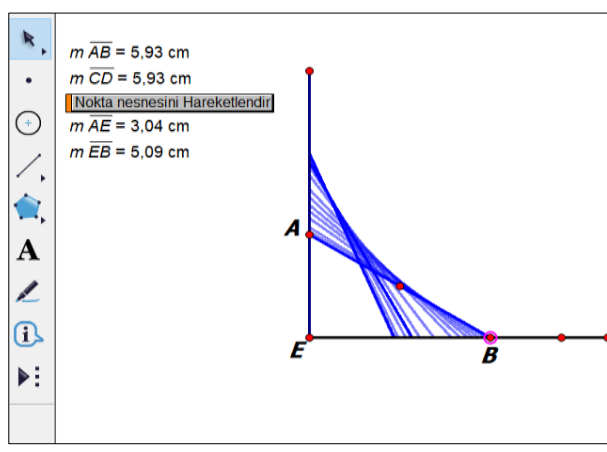

Figure 5a. Dynamic animation constructed by PST4 for Sliding Ladder

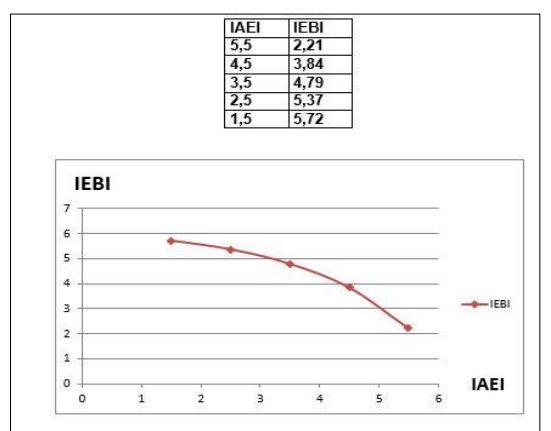

Figure 5b. PST4's work with dynamic animation

PST4 constructed a dynamic animation of Sliding Ladder showing the height of the upper edge as IAEI and the distance of the bottom edge to the wall as IEBI. She then collected some data regarding the measures of these lengths by using the properties of the dynamic computer environment. Later on, she transferred the data to the MS Excel and obtained the graph in Figure 5b. When compared to her way of thinking in paper and pencil solution, it is observable that she started to think with primary variables and using direct and systematic coordination. After that, PST4 decreased the values of IAEI with equal amounts ( 1 unit increments) and wrote down the corresponding IEBI values. She used direct and systematic coordination here. As a result, PST4 obtained the graph in Figure 5b, but she had difficulty in explaining the concavity of the graph that she sketched by MS Excel. A small episode from the interview is provided below in which PST4 explained her way of reasoning with the dynamic animation of Sliding Ladder.

Researcher: Yes at first you thought as a function of time in your graphs [see the linear graphs in Figure 4a].

PST4: Yes, actually I thought as a function of time. I mean as the height was decreasing as a function of time, the horizontal distance was increasing as a function of time.

Researcher: Why did you think as if there was a linear relationship?

PST4: I didn't think very much indeed. I just figured out as one of the variables was decreasing, the other was increasing.

Researcher: You changed the graph [The graph seen in Figure 4b], why?

PST4: Yes, after watching the animation, I felt that the height and horizontal distance were not changing linearly. As the ladder slides down, a figure of the concave upward curve appears [Figure 5a]

Researcher: What does that mean?

PST4: The slopes are gradually getting smaller... I mean the ratio of change in height to the change in horizontal distance is gradually decreasing.

Researcher: Well, you obtained this graph by MS Excel [Concave down decreasing graph] How do you interpret this? What do you think about this graph?

PST4: [Thinking for a few seconds]. I don't know at the moment, I had also surprised when I got this graph via Excel... Yes, I drew this concave up decreasing graph with the idea that slopes were getting smaller and smaller, and I am still thinking in the same way. But, slopes are gradually increasing here, I am confused at the moment.

PST4 indicated that she thought these two variables separately, each was changing with respect to time, in her paper and pencil solution. She could not directly coordinate these two variables. PST4 also indicated that she drew linear graphs because she did not involve in-depth thinking on the situation. PST4 indicated that she decided to revise the linear graphs to a concave up decreasing graph (see Figure 4b) after constructing and watching the dynamic animation. For the reason of drawing a concave upward decreasing graph, PST4 indicated that she observed and felt this kind of curve while watching the sliding ladder animation. PST4 surprised with the concave downward decreasing graph sketched by MS Excel. She also indicated her ongoing difficulty in comprehending this concave down graph. In the following parts of the interview, we asked PST4 to think for an explanation about the graph obtained by MS Excel.

Researcher: Yes PST4, could you please try to explain the difference between these two graphs?

PST4: [Thinking]... It can be related to data, here I drew perceptually. Using the data, we got this concave down graph.

Researcher: Well, how can you explain this?

PST4: I am trying to understand [Silence]. Here we are intuitively drawing the graph without knowing the exact values of sides and hypotenuse, but in MS Excel we worked with the real values so this must be the true one.

Researcher: Then, what do you think about the benefits of computer-based environments, at least for this activity?

PST4: For this activity, the technology showed our incorrect way of thinking. We collected data and we sketched the graph with the data, but in another case, we were drawing the graph roughly. I got really surprised because MS Excel sketched a different graph that I did not expect. When I watch the animation of the sliding ladder, I fell as if the graph should be as my first drawing. I cannot think differently at the moment. 
In the episode above, PST4 had difficulty in explaining the concave down decreasing graph. Because PST4 corrected her linear graphs as a concave up decreasing graph with the animation, least to say, dynamic animation context helped PST4 thinking with the primary variables and using the direct coordination. The dynamic computer environment provided PST4 to compute the numerical values of the variables, and she obtained an accurate graph via MS Excel using these values. However, PST4's difficulty in explaining this graph shows her inability to envision direct and systematic coordination in her mind. Similarly, PST4 continued to quantify the rate of change intuitively (gross quantification) instead of using extensive or intensive quantification. Therefore, for PST4, the dynamic computer environment in Sliding Ladder activity played a mediating tool role in lowering the cognitive load. For Space Shuttle activity, PST4 thought with primary variables, used direct coordination, and perceptually quantified the rate of change. With dynamic animation of Space Shuttle, PST4 collected data again and she could be able to explain the concave down increasing graph by appropriately using direct and systematic coordination. The dynamic computer environment played a mediating tool role in Sliding Ladder activity while it supported her to be able to use direct and systematic coordination in Space Shuttle.

\subsection{Prospective Mathematics Teacher Coded as PST6}

For Water Tank activity, PST6 thought with the primary variables and she used direct coordination (see Figure 6a). However, linear graphs with the verbal explanations show PST6's use of gross quantification for quantifying the rate of change. As can be seen in Figures $6 a-6 b-6 c$, PST6 consistently drew linear graphs for all activities. In other words, PST6 thought with the primary variables, she directly coordinated the variables throughout all activities, but she quantified the rate of change by using gross quantification.

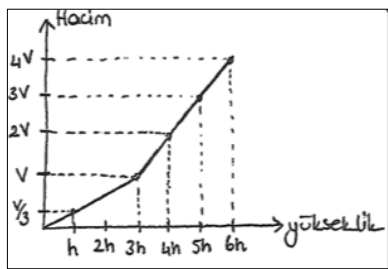

Figure 6a. PST6's paperpencil graph for Water Tank

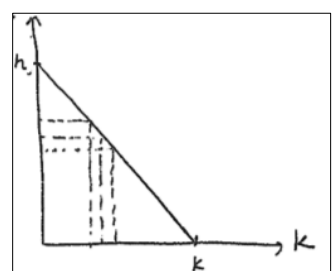

Figure 6b. PST6's paperpencil graph for Sliding Ladder

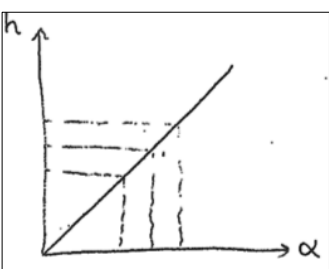

Figure 6c. PST6 paper-pencil graph for Space Shuttle

After constructing the dynamic animations, for Water Tank activity, PST6 drew a concave up increasing graph for the bottom (conical part) and a linear graph for the cylindrical part with a sharp corner at the transition point. PST6 could construct the dynamic animation for Sliding Ladder, but again she did not make any correction in her linear graph. PST6 decided the graphs only by watching the animations without using the data collection and data analysis properties of the dynamic computer environment.

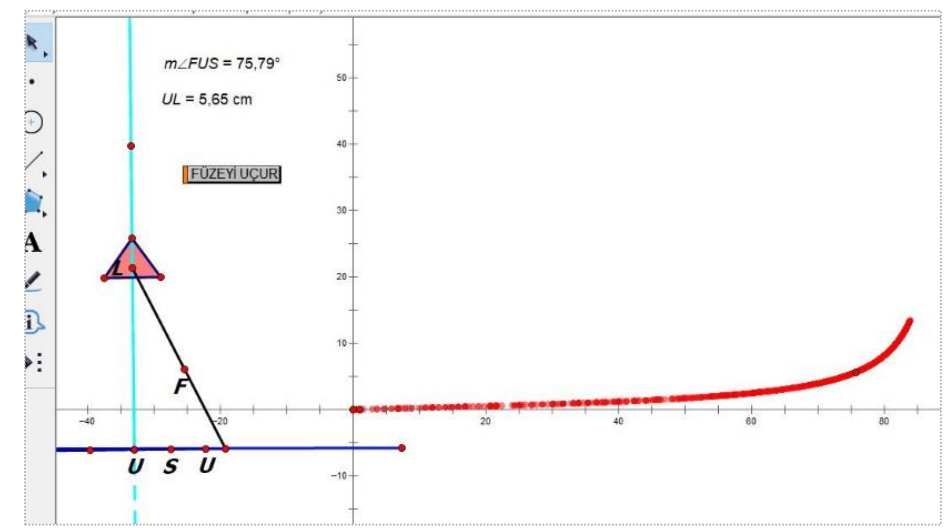

Figure 7. Dynamic animation constructed by PST6 for Space Shuttle

For the Space Shuttle activity, on the other hand, PST6 corrected her paper and pencil linear graph as a concave up, increasing graph (see Figure7). By using the tracking point property of the dynamic computer environment, she obtained the graph showing the change in height as a function of the angle as in Figure 7. In the episode below, we asked PST6 about her way of thinking while working with the dynamic animation of Space Shuttle activity.

Researcher: Okay, let's continue with the Space Shuttle. How did you think?

PST6: Indeed, I thought linearly once again in my paper-pencil solution, but later I realized my mistake. I mean, I thought in a way that as height increases angle also increases, and so I drew a linear graph. After 
constructing the animation, I got measures of height and angle variables. Later, I realized a non-linear graph when I drew a dynamic graph by using the track point property.

Researcher: Well, what does that graph mean, could you please explain?

PST6: In fact, the unit of height is in meter and the other is in degree. Therefore we should not expect the same amount of increase in both. Or let me say differently, let's change the angle with equal amounts and focus on the change in height. It is difficult to change the angle with equal amounts but it will be something like that...

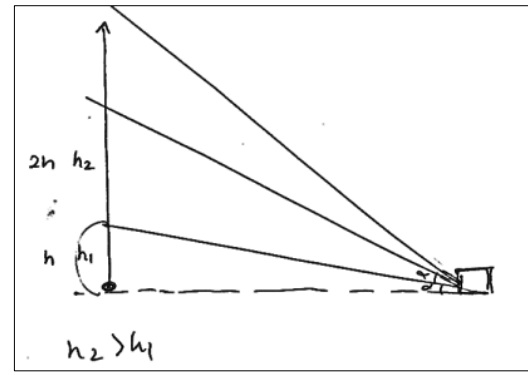

Figure 8. One of PST6's drawings during the interview

Researcher: All right, what do you observe?

PST6: Hmm, yeah height is increasing more. It is clear. Even, we can see how height gets bigger if we add one more alpha.

Researcher: Well, what does that mean on a graph?

PST6: If we plot on a graph, again by increasing the alpha with equal amounts... For example, let's say $h$ here, the other interval is 3 for instance. I mean, the increase in h is getting bigger, so the graph will be increasingly increasing.

Researcher: All right, once for all, if any, how did the dynamic animations contribute you?

PST6: Yes, they might contribute me indeed. I realized that I had a superficial look for all activities. I could think indepth also by getting the measures of variables in Sliding Ladder for example. I could not think to get the measures of the variables...

Researcher: What do you think about the other ways of using these dynamic animations in the classroom?

PST6: In my opinion, they are necessary because it's better to see taking shape of the graph dynamically rather than just drawing it. I mean, in this activity, for example, we animated the Space Shuttle and at the same time, we dynamically observed how the graph takes shape. This would be more meaningful for students.

As PST6 indicated in the interview, in the paper and pencil solutions, she thought as if there was a linear relationship between variables. Also, it is understood that PST6 did not think in-depth about the changes in variables in relation to each other. Even though PST6 thought with the primary variables, she did not use direct and systematic coordination, and she perceptually quantified the rate of change. It is clear that only constructing and watching the dynamic animations without using its further properties had a minimal effect on PST6's ways of thinking. PST6 could be able to use the data collection and further properties of the dynamic computer environment only during the Space Shuttle activity which was implemented as the last. After getting a different graph with the dynamic computer environment, she needed to rethink her paper-pencil solution for Space Shuttle. PST6 started to use direct and systematic coordination as she changed the angle variable with equal amounts and considered the simultaneous change in the height variable. During the interview, we also asked PST6 to construct a dynamic graph for Sliding Ladder activity. PST6 could be able to get a concave down decreasing graph by using the track point property, but she had difficulty in interpreting this graph. Regarding the question about the benefits of dynamic animations, as other prospective teachers did, PST6 also emphasized its data collection and data analysis properties.

\subsection{Prospective Mathematics Teacher Coded as PST11}

For Water Tank activity, PST11 thought with the primary variables (by reversing their orders), and she could use direct coordination (see Figure 9a). Fort the volume versus height graph, PST11 drew linear graphs for both parts of the tank. This was interpreted as an indicator of using the gross quantification for quantifying the rate of change. As seen in Figure 9b, for the Sliding Ladder activity, PST11 thought by relying on the algebraic expression and so she drew a circle at the first quadrant. However, because she thought with the algebraic expression $x^{2}+y^{2}=r^{2}$ (where $r$ stands for the length of the ladder) and drew the graph based on it, she did not reflect clearly in her verbal explanation how she attended covariational reasoning at different dimensions. For Space Shuttle activity, on the other hand, PST11 provided just a verbal explanation indicating that height and angle variables were directly proportional (see Figure 9c). PST11 thought with the primary variables throughout all the activities. She could coordinate the variables directly, but she perceptually quantified the rate of change. 


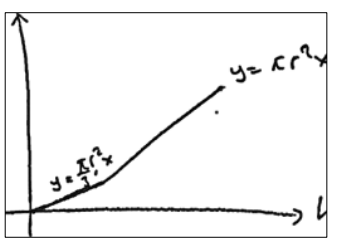

Figure 9a. PST11's

paper-pencil graph for Water Tank

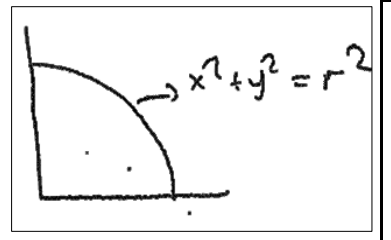

Figure 9b. PST11's

paper-pencil graph for Sliding Ladder

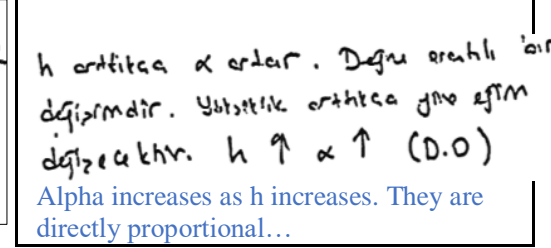

Figure 9c. PST11's paper-pencil solution for Space Shuttle.

After constructing the dynamic animation, for Water Tank activity, PST11 thought with the primary variables, and she drew a concave up, increasing graph for the conical part and a linear graph for the cylindrical part. The graph of PST11 was involving a sharp corner at the transition point. In the Sliding Ladder activity, because she was sure with her paper-pencil graph drawn based on the algebraic equation, she did not need to rethink about the graph while working with the dynamic animation. Also, she indicated that there was no need to provide a verbal explanation about the situation as it was clear with the algebraic equation. For the Space Shuttle activity, as she did in the paper-pencil solution, she provided the same verbal explanation indicating the direct proportionality between the height and angle variables after watching the animation. In the episode below, PST11 explained her way of reasoning regarding the Space Shuttle activity.

Researcher: Well, how did you think while solving the Space Shuttle? I cannot see a graph in your paper-pencil solution, there is only a verbal explanation.

PST11: Yeah, I did not draw a graph. I mean, as the shuttle goes up the angle of the camera increases. Therefore I said they were directly proportional... But here the slope gets bigger...

Researcher: Let's look at the animation again... what graph can we get? It was asking how height and angle were changing together..

PST11: Yes, I did not draw a graph ... both are increasing. If we consider the situation as a triangle, the bottom edge is constant. And therefore I said directly proportional because of height increases as the angle increases.

Researcher: What does directly proportional mean?

PST11: It means as one of the variables increases the other one also increases...

Researcher: Does it mean a linear relationship?

PST11: Not linear, height is continuously increasing, so the angle is also increasing. It should be like a parabola... It should be parabolic because the slope is changing. It will be concave up or concave down increasing.

Researcher: Ok, which one? You can look at the animation again and you can take some measures...

PST11: [Watching the animation] I did not measure the angle values. Let me measure, now it is 45 degrees, and height is 7,57 (she got a few more values). Okay, the angle is increasing more, while height is increasing less...

Researcher: As the angle increases more, height increases less, how did you decide that?

PST11: [Watching the animation] Yes, as angle increases more, height increases less.

As seen in the episode above and Figure 9c, PST11 described the increase in height and angle variables as direct proportionality. However, because she additionally indicated the nonlinearity, PST11 might have a misconception about the direct proportion concept. After watching the animation again by measuring the values of height and angle variables, she explained "as the angle increases more, height increases less". This verbal expression shows that PST11 envisioned the changes in height and angle variables separately without coordinating the simultaneous covariation. For other activities, PST11 also had difficulty in verbally explaining by directly coordinating the simultaneous change in variables although she could plot them on true axes. In the following parts of the interview, she got the idea of direct and systematic coordination with the guidance of the researcher.

Researcher: You can record some of the values if you want. For instance, height is 5,47 when the angle is 36 degrees. What happens if we change the angle with equal amounts?

PST11: Hmmm, okay, let me change the angle equally. Height is 5,47 when the angle is measured 36 degrees; height is 7,40 when 45 degrees; let me increase with one more 9-unit... height is 10,15 when the angle is measured 54 , and height is 14,33 when the angle is 63 degrees..

Researcher: What do you see here?

PST11: We changed the height with 9 unit increments and correspondingly height increased by 2 units first, later 3 units, and 4 units. Okay, it clear, then height increased more...

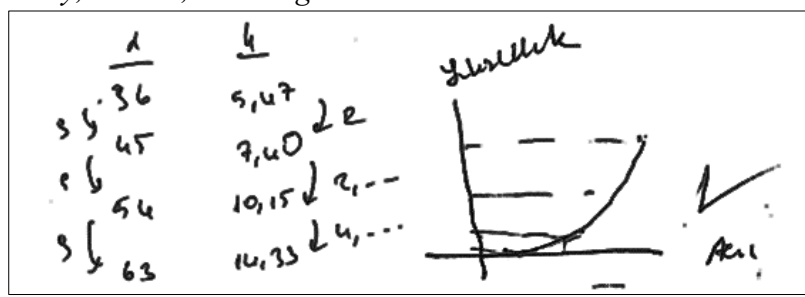

Figure 10: An excerpt from PST11's work for Space Shuttle during the interview 
Researcher: Now, what does that mean?

PST11: It means, when we change the angle measures with equal amounts, the increase in the values of height gets bigger. In my graph, it was going downward, but then it should be something like that (drawing a concave upward increasing graph).

Researcher: Well, then can we say the dynamic animation did not clarify this idea?

PST11: Yes in fact, I made a mistake when I just watched the animation. But, it worked out when we computed some of the values. I had measured the height and slope values, but I could not figure out measuring the angle. It might be so helpful if I properly used it.

Direct and systematic coordination can be seen as a critical indicator of high levels of covariational reasoning. When we analyzed PST11's way of thinking, she had difficulties in directly coordinating the variables up to the idea that changing one of the variables with equal amounts prompted by the researcher. In the episode above, PST11 could be able to use direct and systematic coordination by keeping the changes in one of the variables constant just after the clue prompted by the researcher. As seen in Figure 10, PST11 could be able to explain how two variables change together after collecting and working on a few numerical data. Regarding the question about the possible benefits of dynamic animations, she indicated that she realized its potential for collecting and analyzing data during the interview. Because PST11 did not use data collection and graph drawing properties at the beginning, the dynamic animations did not contribute her ways of thinking about the activities.

\section{Discussion and Conclusion}

Prospective mathematics teachers' ways of thinking appeared in their paper and pencil solutions were very similar to the findings of different research studies from many aspects. First of all, the major finding that prospective teachers' tendency of thinking by the secondary variables is in line with many studies (e.g., Carlson et al., 2002; Johnson, 2012; Kertil, 2014; Kertil et al., 2019; Stalvey \& Vidakovic, 2015; Şen-Zeytun et al., 2010). As also observed in the studies conducted by middle grade or university level students, in this study, prospective mathematics teachers also invoked the time variable while thinking about the simultaneously changing quantities such as volume-height and angle-height (Johnson, 2012; Keene, 2007; Stalvey \& Vidakovic, 2015). We don't mean the inaccuracy of thinking with the secondary variables here, rather we try to emphasize that this way of thinking may result in difficulties for a person in the subsequent phases or other dimensions of covariational reasoning. Similar difficulties of students at different grade levels can be interpreted as the underestimation of covariational reasoning at all levels of schooling. Moreover, prospective mathematics teachers' tendency of considering time as an independent variable can also be related to the frequent usage of time in teaching the real-life interpretation of function (Herbert \& Pierce, 2011, 2012; Jones, 2017; Kertil et al., 2019). On the other hand, as seen in Table 2, the decrease in the frequency of thinking with the secondary variables after working with the dynamic animations shows the potentials of using dynamic computer environments in directing students thinking with the primary variables.

Also, regarding the ways of coordinating the variables, prospective teachers' difficulty in using direct and systematic coordination was in line with the findings of similar studies (e.g., Carlson et al., 2002). This may be the result of thinking with secondary variables as well as it may be related to widespread dependence on the correspondence approach in the teaching of functions (Carlson et al., 2003; Hoffkamp, 2011; Monk, 1992). Direct and systematics coordination has a critical importance for comprehending the situation involving quantities change together and it also critical for high levels of covariational reasoning. Students who can use this way of reasoning seems to comprehend the situations more easily, they can interpret and construct the graphs more accurately, and they can provide more sophisticated verbal explanations. However, the findings of this study show that if the use of direct and systematic coordination can be regularly emphasized and practiced in different contexts, students' ability to use this way of reasoning can be supported. For instance, while PST6 and PST11 did not use direct and systematic coordination in anyway in the beginning, with the dynamic computer environment they could be able to use it.

Thinking with primary or secondary variables, and later, way of coordinating the variables also affects students' way of quantifying the rate of change. In this study, prospective teachers generally did not mention explicitly about the rate of change or they frequently used gross quantification for deciding the concavity while graphically, algebraically or verbally explaining the situations involving two quantities change together. It was observed that prospective teachers who can use direct coordination or direct and systematics coordination can also use extensive quantification for quantifying the rate of change. Intensive quantification was rarely observed. As indicated by Kertil and others (2019), thinking with primary variables followed by the use of direct and systematic coordination does not guarantee the use of extensive or intensive quantification. As observed in the Sliding Ladder activity, the ability to find an appropriate quantitative operation has a critical role even if a person could use direct and systematic coordination. According to the theory of quantitative reasoning, knowledge of quantitative operations are related to giving meaning the mathematical concepts and operations in different reallife contexts (Thompson, 1994, 2011). In other words, at quantifying the rate of change dimension of covariational reasoning, quantitative reasoning is required. Students need a numerical operation to observe the 
change in the dependent variable with equal amounts of change in the independent variable. Students live difficulties in concluding the intensity of change if they could not find an appropriate numerical operation. The finding that prospective teachers' frequent use of gross quantification observed in this study, may also be related to their weakness in quantitative reasoning. Quantitative reasoning of students can be supported by the frequent use of context-based interpretations of mathematical concepts and operations (Thompson, 2011). Therefore, we can also conclude that more experiences of solving problems involving dynamically changing quantities are also needed for prospective mathematics teachers to support their covariational reasoning.

In this study, the animations in dynamic computer environments seem to have a minimal effect on prospective teachers' paper and pencil solutions in general. Although it was not the focus of this paper, this study also confirms research studies reporting the minimum effect of dynamic geometry or algebra software on students' learning if used in a simple way (Donevska-Todorova, 2018). If they used with data collection, dynamic graph, and some other properties, a decrease in the frequency of thinking with secondary variables, which has been described as the starting point of many difficulties in covariational reasoning, was observed in the current study. It was also observed that prospective teachers could be able to use direct coordination or direct and systematic coordination more easily. Some of the prospective teachers needed to rethink the problem situation with the differences between their paper-pencil and computer-based solutions. In this sense, by forcing them to rethink or revise the current ways of thinking, dynamic computer environments supported prospective teachers in developing their covariational reasoning at different dimensions. For some of the prospective teachers, on the other hand, the dynamic animations did not contribute their covariational reasoning, rather they removed the necessity of deep thinking and just played a mediating tool role that helps them to find a result. The use of technology and dynamic computer environments may support students from many aspects one of which is developing their covariational reasoning abilities if used with their data collection properties (Zbiek, Heid, Blume \& Dick, 2007). Here, it seems necessary for teachers to examine and question students about the meaning of the results obtained by dynamic computer environments. For some students, the results obtained by the dynamic computer environment in itself may be an initiator factor for rethinking the situation without the guidance of teachers, but this is not the case for all students. At least for some students, teacher questioning seems necessary about the results to increase the contribution of the dynamic computer environment.

\section{Suggestions}

As final words, although this study has parallel findings with many studies in the literature, it is limited with the participants and the activities used. Indeed, the study conducted by Johnson and others (2017) showed that students' covariational reasoning may change from task to task and sometimes they cannot transfer easily a particular way of thinking across different tasks. Therefore, similar studies can be conducted for understanding and developing the covariational reasoning of students from different grade levels. More studies on this issue may contribute us to clarify the meaning of covariational reasoning and so developing new and effective pedagogical strategies in developing this ability. For example, as also observed in this study, more studies can be conducted on describing the covariational reasoning of students who prefer to think with algebraic equations (Thompson et al., 2017), and the relationship between covariational reasoning and other thinking skills. Moreover, the possible effects of technology on developing covariational reasoning of students at different grade levels, depending on teachers' way of using it in mathematics classrooms, worth further investigations. Similarly, more studies are needed on clarifying the role of covariational reasoning for the understanding of the basic mathematical concepts such as ratio and proportion, linear equations, function, derivative and integration. Even, the approaches adopted in the curricular materials for the teaching of these concepts can be analyzed in terms of their emphasis on covariational reasoning. Yet, the inadequacy of covariational reasoning for teachers, prospective teachers, and students from different grade levels shows us that the problem can be related to the common practices used in the teaching of mathematical concepts throughout the years. 
Appendix 1. Water Tank, Sliding Ladder, and Space Shuttle activities

\section{Water Tank}

A water tank in the shape of a cone and cylinder for the bottom and upper parts respectively are seen in the figure. The tank is being filled with water at a constant flow rate. Provide an explanation of how the height changes with respect to the volume of water.

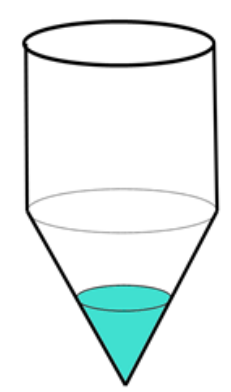

\section{Sliding Ladder}

A ladder leans against a wall (at Point B) of a house at a nearly vertical position. Its base (Point A) starts to slide away at a constant rate. As the ladder slides away, how does the height of Point B from the ground and the distance of Point A from the Wall change together? Explain by drawing the graph.

\section{Space Shuttle}

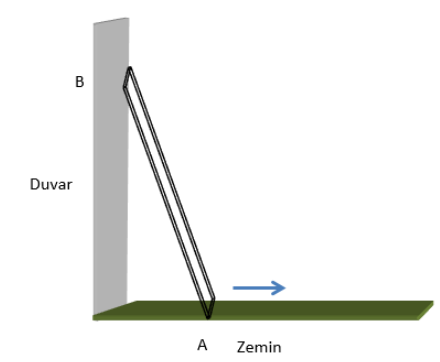

A cameraman who wants to display the launching of a space shuttle should change the angle of the camera until it disappears from view. Accordingly, how the angle of the camera $(\alpha)$ and the height of the space shuttle from the ground change together? Explain by also sketching its graph.

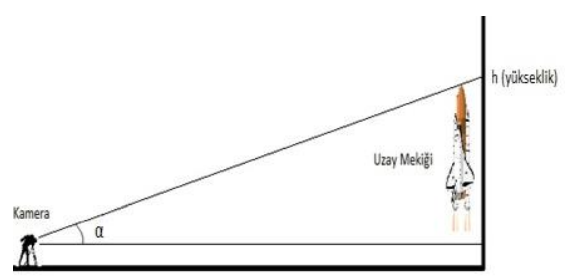




\section{Matematik Öğretmen Adaylarının Kovaryasyonel Düşünme Becerileri: Dinamik Animasyonlar Nasıl Etkiliyor?}

\section{Giriş}

Niceliklerdeki değişim, değişkenlik ve değişim oranı gibi kavramlar her seviyeden matematik konularının alt yapısını oluşturmaktadır (Confrey \& Smith, 1994; Thompson, 1994). İki niceliğin birlikte ve eş zamanlı değişimi ile ilgili düşünme biçimleri alan yazında kovaryasyonel düşünme kavramsal yapısı bağlamında ele alınmaktadır (Carlson, Jacobs, Coe, Larsen \& Hsu, 2002; Johnson, 2012; Saldanha \& Thompson, 1998; Thompson \& Carlson, 2017). Carlson ve arkadaşlarına (2002) göre kovaryasyonel düşünme, eş zamanlı olarak değisşen iki nicelikteki değişimlerin birbirleriyle ilişkisinin koordine edilmesi sürecindeki zihinsel faaliyetlerden oluşmaktadır. $\mathrm{Bu}$ zihinsel faaliyetler gelişimsel olarak alt düzeyden üst düzeye doğru sınıflandırılmıştır. Thompson ve Carlson'a (2017) göre ileri düzey kovaryasyonel düşünme ise, eş zamanlı olarak değişen iki niceliğin ölçülen niteliklerinin bir bütün olarak görüldüğü yeni bir zihinsel nesnenin (ör., nicelik1, nicelik2, nicelik1-nicelik2) oluşturulabilmesidir. Örneğin, su ile doldurulan bir depo için suyun hacmi ve suyun depo içerisindeki yüksekliği eş zamanlı ve dinamik olarak değişen iki niceliktir. Yeni bir zihinsel nesnenin oluşturması, bu niceliklerin ayrı ayrı ve birlikte değişimini (hacim, yükseklik, hacim-yükseklik) bir bütün olarak yorumlayabilme düzeyi ile ilgilidir.

Kovaryasyonel düşünme becerisi eş zamanlı ve dinamik olarak değişen iki nicelikteki değişimleri koordine edip edememe; niceliklerden sadece birindeki değişime odaklanma veya her ikisindeki değişimi birlikte görebilme; değişimlerin ayrı ayrı yoğunluklarına veya değişim oranına odaklanıp odaklanamama gibi düşünmeleri kapsayan bir kavramdır (Carlson ve ark., 2002; Thompson \& Carlson, 2017). Thompson ve Carlson'a (2017) göre, kovaryasyonel düşünme gelişimsel olup, bu beceriye sahip olma düzeyi bakımından öğrenciler farklı seviyelerde olabilmektedir. Kovaryasyonel düşünme becerisi bazı önemli matematiksel kavramların anlaşılmasında önemli rol oynamaktadır. Birçok araştırmada, oran-orantı, fonksiyon, değişim oranı, türev ve integral gibi kavramlar ile ilgili öğrenci ve öğretmen zorluklarının temel sebeplerinden birisinin kovaryasyonel düşünme becerilerindeki eksiklik olduğu görülmektedir (Carlson, 1998; Carlson ve ark., 2002; Kertil, 2014; Monk, 1992; Thompson, 1994). Örneğin, fonksiyon kavramının öğretiminde girdi-çıktı yaklaşımının ön planda olması, öğrencilerde fonksiyon kavramının değişkenler arasındaki dinamik ve eş zamanlı değişim fikri olarak gelişmesini engelleyici bir unsur olmaktadır (Carlson, 1998; Confrey \& Smith, 1994; Oehrtman, Carlson \& Thompson, 2008; Stroup, 2002; Thompson \& Carlson, 2017). Oehrtman ve arkadaşları (2008) tarafından yapılan çalışma, fonksiyon kavramının sadece eşleme (girdi-çıktı) yaklaşımıyla verilmesi, öğrencilerin bu kavramı dinamik bir ilişki olarak anlamlandırmakta zorlanmalarına sebep olduğunu göstermektedir. Kovaryasyonel düşünme eşzamanlı ve dinamik değişimlere odaklandığı için fonksiyon kavramının daha iyi anlaşılmasına yardımcı olabilmektedir (Carlson ve ark., 2002; Monk, 1992; Thompson \& Carlson, 2017).

Benzer şekilde, öğretmen ve öğrencilerin oran-orantı kavramları ile ilgili zorluklarının temelinde de kovaryasyonel düşünme becerisinin eksik olması yatmaktadır (ör., Herbert \& Pierce, 2011, 2012; Lobato \& Ellis, 2010). Örneğin, bir aracın veya cismin hızı sorulduğunda, öğrenciler cismin gittiği mesafeye bakmadan sadece zaman değişkenine odaklanarak cevap verebilmektedirler (Lobato \& Thanheiser, 2002). Yine ilköğretim düzeyinde oran-orantı konusunun kovaryonel düşünmeye odaklanmadan öğretilmesi, ilerleyen seviyelerde öğrencilerde doğrusal ilişkinin yanlış kullanımına sebep olmaktadır (De Bock, Van Dooren, Janssens \& Verschaffel, 2002; Monk, 1992). Öğrenciler iki niceliğin birlikte değişimini içeren her durumda, değişim oranları sabit olmasa bile doğrusal ilişki varmış gibi düşünebilmektedir. İleri düzey kovaryasyonel düşünebilme becerisine sahip kişiler iki değişkenin ayrı ayrı ve birlikte değişimlerine odaklandığından doğrusal ve doğrusal olmayan ilişki içeren durumları kolaylıkla ayırt edebilmekte, grafik üzerinde ve sözel olarak daha doğru ifade edebilmektedir (Castillo-Garsow, 2012; Stroup, 2002; Thompson, Hatfield, Yoon, Joshua \& Byerley, 2017).

Öğrencilerin sınıf seviyeleri ilerledikçe ilginç bir şekilde kovaryasyonel düşünme becerilerinin fazla gelişmediği, ileri sınıf seviyesinde olanların kovaryasyonel düşünmede daha çok zorlandıkları görülmektedir (Thompson ve ark., 2017). Thompson ve arkadaşlarına (2017) göre bu, öğrencilerin öğrenim hayatları boyunca maruz kaldıkları öğrenme biçiminin, eş zamanlı değişen iki niceliği bir bütün olarak görme pratiğini uygulamamış ve matematiksel kavramlara bu şekilde bakmamış olmalarının doğal bir sonucudur. Bu nedenle, kovaryasyonel düşünme becerisinin alt düzey sınıf seviyelerinden itibaren ele alınması gerekmektedir.

Ülkemizde yapılan bazı çalışmalarda elde edilen sonuçlarda da öğrenci ve öğretmenlerin kovaryasyonel düşünme becerilerinin yeterli olmadığ 1 görülmektedir (Kertil, Erbaş \& Çetinkaya, 2019; Yemen-Karpuzcu, Ulusoy \& Işıksal-Bostan, 2017; Şen-Zeytun, Çetinkaya \& Erbaş, 2010). Birçok kavramın temelini oluşturan kovaryasyonel düşünme becerisi hakkında matematik öğretmenlerinin farkındalıklarının ve yeterli düzeyde mesleki alan bilgisine sahip olmalarının gerekliliği de ortadadır. Birçok araştırmada, her seviyeden öğrenci, matematik öğretmeni ve öğretmen adayları için kovaryasyonel düşünme becerilerini geliş̧irmeye yönelik çeşitli uygulamalar ve araştırmalar yapılmasının bir ihtiyaç olduğu vurgulanmaktadır (Ärlebäck, Doerr \& O'Neil, 2013; 
Carlson ve ark., 2002; Carlson, Larsen \& Lesh, 2003; Thompson \& Carlson, 2017; Thompson ve ark., 2017). Dinamik animasyonlarla desteklenmiş bilgisayar destekli etkinlikler kullanıldığında öğrencilerin fonksiyon kavramı ile ilgili önemli fikirler geliştirebileceği ve kovaryasyonel düşünme becerilerinin de desteklenebileceği bazı çalışmalarda ortaya konulmuştur (ör., Hoffkamp, 2011; Johnson, McClintock \& Hornbein, 2017). Fakat bu konu üzerine farklı bağlamlarda kapsamlı çalışmalar yapılması önerilmektedir (Johnson ve ark., 2017; Thompson ve ark., 2017). Bu çalışma kapsamında, dinamik ve eş zamanlı olarak değişen nicelikler içeren bir dizi modelleme etkinliği kullanılarak ilköğretim matematik öğretmen adaylarının kovaryasyonel düşünme becerilerini ve dinamik animasyonların bu becerileri nasıl etkilediği incelenmiştir. Bu çalışmada kovaryasyonel düşünme becerisi matematiksel bir kavram özelinde incelenmemiş olsa da çalışma kapsamında kullanılan etkinlikler fonksiyon, fonksiyon grafikleri ve değişim oranı gibi kavramları içermektedir. Çalışmaya yön veren araştırma soruları şunlardır:

i. İlköğretim matematik öğretmen adaylarının, modelleme etkinliklerini çözüm sürecinde sergiledikleri kovaryasyonel düşünme becerileri nasıldır?

ii. Etkinlik bağlamlarının bilgisayar destekli dinamik animasyonlar ile desteklenmesi kovaryasyonel düşünme becerilerini nasıl etkilemektedir?

\subsection{Kavramsal Çerçeve}

Kovaryasyonel düşünme becerileri ile ilgili ilk olarak Carlson ve arkadaşları (2002) tarafindan öğrencilerin zihinsel aktivitelerine göre beş seviyeden oluşan bir kavramsallaştırma yapılmıştır. Carlson ve arkadaşları (2002, s.358) tarafindan yapılan tanımlamaya göre kovaryasyonel düşünme becerileri (i) koordinasyon, (ii) birlikte değişimin yönünü belirleme, (iii) niceliksel koordinasyon, (iv) ortalama değişim oranı ve (v) anlık değişim oranı olmak üzere alt düzeyden en üst düzeye doğru beş seviyeden oluşmaktadır. Carlson ve arkadaşları (2002) bu seviyelerin her biri için belirli zihinsel aktiviteler tanımlanmış ve bu zihinsel aktiviteleri yansıtıp yansitmama durumuna göre öğrencilerin seviyelerini belirlemişlerdir. Bu kavramsal çerçeve kovaryasyonel düşünmeye odaklanan çalışmalarda birçok araştırmacı tarafindan kullanılmış, fakat öğrencilerin gösterdiği düşünme çeşitliliğinin tamamını betimlemekte yetersiz kaldığı görülmüştür (ör., Ärlebäck ve ark., 2013; Carlson ve ark., 2002, 2003; Castillo-Garsow, 2012).

Thompson ve Carlson (2017) tarafindan güncellenen kavramsal çerçevede ise kovaryasyonel düşünmenin seviyeleri; (i) koordine edememe, (ii) değerlerin ön koordinasyonu (senkronize edememe), (iii) değerlerin kabaca koordine edilmesi, (iv) değerleri koordine edebilme, (v) kesikli sürekli kovaryasyon, (vi) düzgün (kesiksiz) sürekli kovaryasyon şeklinde sınıflandırılmıştır. Bu seviyeler iki değişkenin eş zamanlı değişimi üzerine öğrencilerin muhtemel düşünmelerini tanımlamak üzere farklı ve uzun süreli çalsşmaların bulguları temel alınarak oluşturulmuştur. Örneğin, kesikli sürekli kovaryasyon ve düzgün (kesiksiz) sürekli kovaryasyon kavramları ilk olarak Castillo-Garsow (2012) tarafindan yapılan üstel fonksiyonlar üzerine öğrencilerin niceliksel düşünme becerilerini incelediği çalışmasında ortaya çıkmıştır. Castillo-Garsow (2012) doğrusal olmayan ve üstel fonksiyonlarla modellenebilen durumların anlaşılmasında, düzgün (kesiksiz) sürekli kovaryasyonel düşünme becerisinin öğrenciler için kritik öneme sahip olduğunu göstermiştir.

Kesikli sürekli kovaryasyon iki değişkenin birlikte değişimi hakkında küçük aralıklara bölerek kesik kesik düşünmeyi ifade ederken, düzgün (kesiksiz) sürekli kovaryasyon ise iki değişkenin birlikte değişimini küçük aralıklara bölme ihtiyacı hissetmeden sürekli ve kesiksiz olarak düşünebilmeyi ifade etmektedir. Örneğin, hızı $100 \mathrm{~km} / \mathrm{saat}$ olan bir araç için, her bir saatte $100 \mathrm{~km}$ yol alacağını veya her iki saatlik dilimlerde $200 \mathrm{~km}$ yol alacağını düşünmek kesikli sürekli kovaryasyon içermektedir. Aynı araç için zaman aralıkları istenildiği kadar küçük alınsa bile (ör., 1'er saniye, 1'er dakika) yol ile zaman değişkenlerinin birlikte değişimlerinin veya değişim oranlarının aynı kalacağını düşünebilme kesiksiz sürekli kovaryasyonu gerektirmektedir.

Tablo 1. Kovaryasyonel düşünme: Boyutları ve alt bileşenleri (Kertil ve ark., 2019)

Boyutlar ve Alt Bileşenleri

1. Değişkenlerin Belirlenmesi

Birincil değişkenlerle düşünme

İkincil değişkenlerle düşünme

Değişkenlerin rolünü

değiştirme

2. Değişkenlerin Koordine Edilmesi

Koordine edememe

Dolaylı koordinasyon

Doğrudan koordinasyon

Doğrudan ve sistematik koordinasyon

Açıklama

Eş zamanlı değişen iki değişkenden birisini bağımlı diğerini ise bağımsız değişken olarak alma

Problem bağlamında verilmeyen üçüncü bir değişken ile düşünme

Bağımlı ve bağımsız değişkenleri yer değiştirerek düşünme

Eş zamanlı değişimleri üçüncü bir değişkene bağlı olarak ayrı ayrı düşünme.

Örn., Hacim zamana bağll olarak artıyor, yükseklik zamana bağll olarak artıyor.

Eş zamanlı değişimleri üçüncü bir değişkene bağlı olarak dolaylı koordine etme.

Örn., Hacim ve yüksekliğin her ikisi de zamana bağll olarak artıyor.

Eş zamanlı değişimler arasında doğrudan ilişki kurma

Örn., Hacim arttıkça yükseklik te artıyor.

Eş zamanlı değişimleri doğrudan ve sistematik koordine etme. Değişkenlerden birini birim birim artırarak diğer değişkenin değişimini gözlemleme.

Örn., birim hacim artışında yükseklik artarak artıyor. 
Tablo 1'in devamı

\begin{tabular}{|c|c|}
\hline \multicolumn{2}{|c|}{ 3. Değişim oranının nicelleştirilmesi (quantification) } \\
\hline $\begin{array}{l}\text { Kabaca veya sezgisel } \\
\text { nicelleştirme }\end{array}$ & $\begin{array}{l}\text { Değişim oranının (hızının) değerini matematiksel bir gerekçelendirme sunmadan, } \\
\text { sezgisel olarak kabaca ifade etme; grafikteki eğriliği yanlış veya eksik ifade etme, } \\
\text { gösterme. Örn., Yükseklik artışı gittikçe yavaşlamaktadır. }\end{array}$ \\
\hline $\begin{array}{l}\text { Miktar odaklı nicelleştirme (örn., } \\
\text { hacim) }\end{array}$ & $\begin{array}{l}\text { Ölçülmesi kolay tek bir niceliğe odaklanma; Değişkenlerden sadece birine odaklanıp } \\
\text { bu değişkenin ardışı aralıklardaki değişimini toplamsal olarak karşılaştırma, } \\
\text { Örn., Eşit hacim aralıklarında, yükseklikteki değişimin gittikçe arttığ } \\
\text { gözlemlenmektedir. }\end{array}$ \\
\hline $\begin{array}{l}\text { Yoğunluk odaklı nicelleştirme } \\
\text { (örn., debi, hız) }\end{array}$ & $\begin{array}{l}\text { İki niceliğin birlikte yorumlanmasıyla oluşan yeni ve soyut bir niceliğe odaklanma; } \\
\text { Değişkenlerden birini birim birim değiştirip (bu birimin sonsuz küçük değerler } \\
\text { alabileceğinin farkında olarak) diğerindeki değişime odaklanma; birlikte değişimde } \\
\text { ortaya çıkan değişim oranını (hızını) yeni bir nicelik olarak görebilme. } \\
\text { Örn., Birim hacim artısında, yükseklik azalan oranda artmaktadır. }\end{array}$ \\
\hline
\end{tabular}

Bu çalışmanın kavramsal çatısını Kertil ve arkadaşları (2019) tarafından tanımlanan kovaryasyonel düşünme boyutları oluşturmaktadır. Kertil ve arkadaşları (2019), Thompson (1994)'un niceliksel (quantitative) düşünme teorisini temel alarak, Thompson ve Carlson'un çerçevesini detaylandırmış ve kovaryasyonel düşünmeyi (i) değişkenlerin belirlenmesi, (ii) değişkenlerin koordine edilmesi ve (iii) değişim oranının nicelleştirilmesi olmak üzere üç boyutta incelemişlerdir. Her bir boyut için alt düşünme becerileri yukarıda Tablo 1'de gösterilmiştir. Tabloda, alt düşünme becerileri ile ilgili verilen örnekler sadece sözel ifadelerden seçilmiş olsa da her bir düşünme şekli cebirsel ve diğer bazı gösterimlerle de desteklenerek tanımlamalar oluşturulmuştur.

\section{Yöntem}

$\mathrm{Bu}$ çalışmada nitel araştırma yöntemlerinden bir grubun, kişinin veya olgunun kendi sınırları içerisinde derinlemesine incelendiği özel durum çalışması (örnek olay) yöntemi kullanılmıştır (Yıldırım \& Şimşek, 2011). Çalışmada analiz birimi olarak bir grup matematik öğretmen adayının eş-zamanlı ve dinamik değişim içeren modelleme problemlerini çözüm sürecinde sergiledikleri kovaryasyonel düşünme becerilerine ve dinamik animasyonların bu becerilere etkileri üzerine odaklanılmıştır.

\subsection{Katılımcilar}

Çalışmanın katılımcıları bir devlet üniversitesinin ilköğretim matematik öğretmenliği programı son sınıf öğrencilerinden Bilgisayar Destekli Matematik Öğretimi dersine devam eden matematik öğretmen adayıdır. Dönem boyunca toplamda 19 ilköğretim matematik öğretmen adayı (12 kı, 7 erkek) derse düzenli devam etmiştir. Fakat Tablo 2'de görüldüğü üzere, Su Deposu etkinliğinin uygulandığı haftada katılımcı sayısı 14, diğer etkinliklerde ise 19 dur.

Katılımcıların büyük çoğunluğu başta Genel Matematik, Analiz-1, Analiz-2, Analitik Geometri, Lineer Cebir gibi alan dersleri olmak üzere çeşitli matematik ve matematik eğitimi derslerini ilk 6 dönem boyunca almış ve başarıyla tamamlamışlardır. Çalışma bağlamında kullanılan modelleme etkinliklerin gerektirdiği matematik bilgisi bakımından tüm katılımcıların birbirlerine yakın bilgi birikimine sahip olduğu söylenebilir.

\subsection{Uygulama ve Veri Toplama Süreci}

Veri toplama aracı olarak Kertil (2014)'in çalışmasında kullanılan Su Deposu, Kayan Merdiven ve Uzay Mekiği modelleme etkinlikleri kullanılmıştır (bk. Ek-1). Su Deposu etkinliğinde hacim ile yüksekliğin birlikte nasıl değiştiği; Kayan Merdiven etkinliğinde yatay uzaklık ile yüksekliğin birlikte değişimi; Uzay Mekiği etkinliğinde ise açı ile yüksekliğin birlikte nasıl değiştiği sorulmaktadır. Çalışmada kullanılan etkinlikler, Lesh ve arkadaşları (2000) tarafından belirlenen iyi bir matematiksel modelleme etkinliğinin taşıması gereken temel özelliklerin tamamını karşılamasa da, bir gerçek hayat bağlamı içermesi ve farklı düşünme biçimlerine açık olması sebebiyle modelleme etkinliği olarak isimlendirilmiştir.

Her bir etkinlik önce kâğıt-kalem ile öğretmen adaylarına bireysel olarak çözdürülmüştür. Her bir etkinlikte bireysel (kâğıt-kalem ile) çözümler için yaklaşık yarım saat süre verilmiştir. Çözüm kâğıtları toplandıktan sonra öğretmen adaylarından aynı etkinlikler üzerine tercih ettikleri uygun yazılımlar ile dinamik animasyonlar oluşturarak tekrar çalışmaları istenmiştir. Daha sonra onlardan dinamik animasyonlar üzerinde yaptıkları gözlem ve ölçümler sonrasında önceki düşüncelerinde ne tür farklılaşmalar olduğunu anlattıkları düşünce raporları istenmiştir. Öğretmen adayları, Kayan merdiven ve Uzay mekiği etkinliklerinin dinamik animasyonlarını oluşturmak için Geogebra veya Geometry Sketcpad (GSP) yazılımlarını, Su deposu etkinliği için ise teacher.desmos.com interaktif öğrenme ortamını kullanmışlardır. Kayan Merdiven ve Uzay Mekiği etkinlikleri için hangi programı kullanacaklarına öğretmen adayları yetkinliklerine göre kendileri karar vermiştir. Su Deposu etkinliği için ise farklı depo şekillerine uygun dinamik animasyon oluşturmaya olanak sağladığ için desmos interaktif öğrenme ortamı kullanılmıştır. Önceki haftalarda, ders kapsamında Geogebra, GSP, Desmos ve benzeri uygulamalar kullanılarak benzer çalışmalar yapıldı̆̆ından, öğretmen adaylarının dinamik animasyon 
oluşturabilme ve beraberinde matematiksel kavramları çalışma konusunda her bir programla ilgili yeterli tecrübe ve donamıma sahip olduklarını söylemek mümkündür. Su Deposu, Kayan Merdiven ve Uzay Mekiği modelleme etkinlikleri 3 hafta boyunca uygulanmıştır. Her bir etkinliğin çözümü ve bilgisayar destekli dinamik animasyonunun oluşturulması dönemin 10, 11 ve 12. haftaları olmak üzere üç hafta sürmüştür.

Uygulama sonrasında dört öğretmen adayı ile video kaydı yapılan etkinlik-temelli görüşmeler gerçekleştirilmiştir. Görüşmelerin amacı, öğretmen adaylarının çözüm kâğıtlarında yansıttıkları düşünme becerilerini daha derinlemesine ortaya çıkarmaktır. Görüşme yapılan katılımcıların seçiminde tipik düşünme biçimlerini yansıtma, sosyal iletişim becerisine sahip olma ve gönüllü olma ölçütleri göz önünde bulundurulmuştur.

\subsection{Verilerin Analizi}

Araştırmada elde edilen bulgular Tablo 1'de verilen çerçeveye göre sürekli karşılaştırmalı analiz yöntemiyle incelenmiştir (Strauss \& Corbin, 1998). İlk olarak bütün öğretmen adaylarının her üç etkinlik için bireysel çözüm kâğıtları analiz edilmiştir. Bireysel çözüm kâğıtları analiz edilirken etkinliklerin uygulama sırası göz önünde bulundurulmuştur. Sonrasında, yine bütün öğretmen adayları için dinamik animasyonlar ile yaptıkları çalışma sonucunda çözüm güncellemeleri ve buna yönelik yazdıkları düşünme raporları incelenmiştir. Bu analizler sonucunda elde edilen bulgular sınıfın genel durumunu göstermesi için betimsel olarak tabloda sunulmuştur. Daha sonra, uygulama sonrasında dört öğretmen adayı ile gerçekleştirilen ve deşifresi yapılan görüşmeler derinlemesine analiz edilmiştir. Öğretmen adaylarının nasıl düşündüğünü net bir şekilde ortaya koymak için görüşmelerden bazı kesitler bulgular kısmında sunulmaktadır.

\section{Bulgular}

Bulgular kısmında ilk olarak katılımcıların kovaryasyonel düşünme becerileri ile ilgili genel durumu yansıtmak için elde edilen bulgular betimsel olarak bir tablo ile sunulmaktadır. Bütün öğretmen adaylarının her bir etkinlik için çözüm kâğıtları analiz edilmiş ve kovaryasyonel düşünme çerçevesinin üç farklı boyutunda sergiledikleri düşünme becerileri belirlenerek sıklık tablosu (Tablo 2) oluşturulmuştur.

Tablo 2. Öğretmen adaylarının kâğıt-kalem veya dinamik animasyonlarla destekli çözümlerinde sergiledikleri kovaryasyonel düşünme becerileri

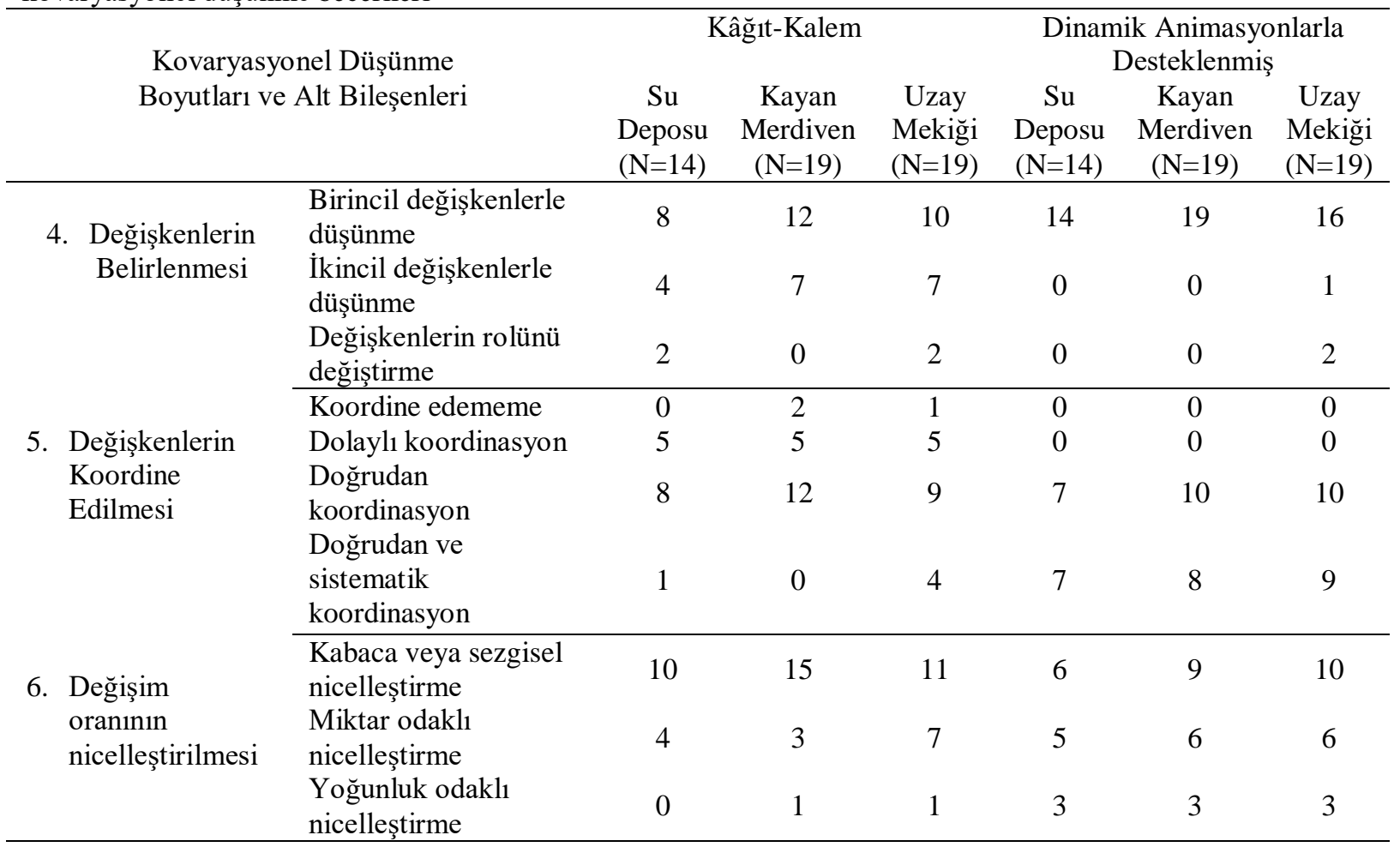

Kovaryasyonel düşünmenin ilk boyutu olan değişkenlerin belirlenmesine bakıldığında, her üç etkinlik için de kâğıt-kalem ile yapılan çözümlerde öğretmen adaylarının ikincil değişkenlerle düşünme sıklığının yüksek olduğu görülmektedir. Aynı etkinlikler üzerine dinamik animasyon oluşturarak yapılan çalışmalarda ise öğretmen adaylarının ikincil değişkenlerle düşünme sıklığının yok denecek kadar azaldığı görülmektedir. Değişkenlerin rolünü değiştirerek düşünme ise, etkinliklerin doğasına bağlı olarak dinamik animasyon ile yapılan çalışmalarda nadiren de olsa ortaya çıkmıştır. İkincil değişkenlerle düşünme yanlış olmamakla beraber kovaryasyonel düşünmenin bir sonraki boyutunda koordine edememe veya dolaylı koordinasyon yaparak düşünmeye sebep 
olmaktadır. Değişkenleri doğrudan ve sistematik koordine edememe ise düşük seviyeli kovaryasyonel düşünme becerisinin bir göstergesidir.

İkinci boyuta bakıldığında, öğretmen adaylarının kâğıt-kalem ile yaptıkları çözümlerinde değişkenlerin eş zamanlı değişimi için sıklıkla dolaylı koordinasyon veya doğrudan koordinasyon kullandıkları gözlemlenmiştir. Dolaylı koordinasyon kullanımı ikincil değişkenlerle düşünmenin doğal bir sonucudur. Üst düzey kovaryasyonel düşünme becerisinin önemli bir göstergesi olan doğrudan ve sistematik koordinasyon ise kâğıt-kalem çözümlerde çok az gözlemlenmiştir. Yine Tablo 2 incelendiğinde, dinamik animasyonlar ile beraber öğretmen adaylarının koordine edememe veya dolayl koordinasyon şeklindeki düşünme şeklinin ortadan kalktığı ve doğrudan koordinasyon ile doğrudan ve sistematik koordinasyon sıklığının arttı̆̆ görülmektedir.

Üçüncü boyuta bakıldığında ise, kâğıt-kalem ile yapılan çözümlerde öğretmen adaylarının, eş zamanlı değişimimden yeni bir nicelik olarak ortaya çıkan değişim oranını (hızını), matematiksel ayrıntıya girmeden, sezgisel olarak veya kabaca nicelleştirmeye çalıştıkları gözlemlenmiştir. Kâğıt-kalem çözümlere kıyasla dinamik animasyonlarla yapılan çözümlerde ise değişim oranına (hızına) yönelik miktar odaklı veya yoğunluk odaklı nicelleştirme kullanımının arttığı görülmektedir. Fakat değişim oranının (hızının) kabaca nicelleştirilmesi halen en sık kullanılan düşünme biçimi olmuştur. Bundan sonraki kısımlarda, farklı etkinliklerde görüşme yapılan dört öğretmen adayının kovaryasyonel düşünmelerini gösteren yazılı çözümlerden ve görüşmelerden örnek kesitlerle desteklenmiş bulgular sunulmaktadır.

\section{1. ÖA3 Kodlu Öğretmen Adayı}

ÖA3 kodlu öğretmen adayının çözümleri incelendiğinde "Su Deposu” etkinliği için birincil değişkenlerle düşünmüş ve değişkenleri doğrudan koordine edebilmiştir (bkz. Şekil 1a). Fakat grafiğe yönelik sözel açıklamasından değişim oranına yönelik kabaca bir nicelleştirme yaptığı görülmüştür. Benzer şekilde "Kayan Merdiven" ve "Uzay Mekiği”" etkinliklerine yönelik kâğıt-kalem çözümünde ÖA3 birincil değişkenlerle düşünmüş ve doğrudan koordinasyon kullanmıştır (bkz. Şekil 1b; Şekil 1c). Kayan Merdiven etkinliğinde, yükseklik ve yatay uzaklık değişkenleri arasında doğrusal bir ilişki olduğunu düşünmesi ÖA3 kodlu öğretmen adayının değişim oranına (hızına) yönelik kabaca nicelleştirme yaptığını göstermektedir. ÖA3 kodlu öğretmen adayının doğrudan ve sistematik koordinasyonun kullanmaması değişim oranını (hızını) kabaca nicelleştirmesinin muhtemel sebebi olarak görülmektedir.

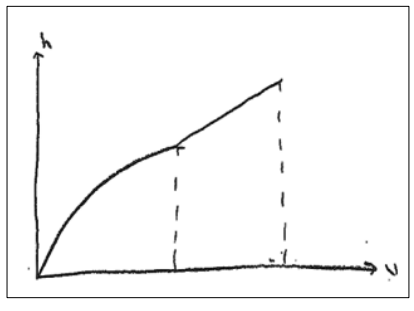

Şekil 1a. ÖA3'ün Su Deposu için kağıt-kalem çözümü

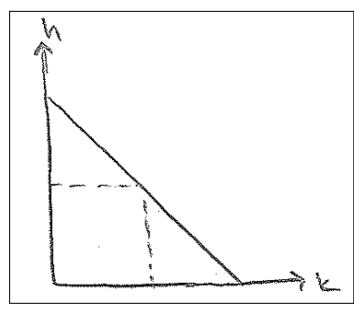

Şekil 1b. ÖA3'ün Kayan Merdiven için kağıt-kalem çözümü

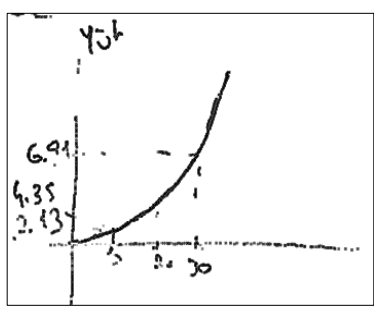

Şekil 1c. ÖA3'ün Uzay Mekiği için kağıt-kalem çözümü

Uzay Mekiği etkinliğinde ise ÖA3 birincil değişkenlerle düşünmüş, ilk defa doğrudan ve sistematik koordinasyon kullanmış, fakat değişim oranını (hızını) yine sezgisel olarak nicelleştirmiştir. Dinamik animasyonlar ile etkinlikler üzerine tekrar çalıştığında ÖA3'ün Su Deposu ve Uzay Mekiği etkinlikleri ile ilgili çözümleri aynı kalmış, Kayan Merdiven etkinliği çözümünde ise değişikliğe gittiği gözlenmiştir. Aşağıda ÖA3 kodlu öğretmen adayının Kayan Merdiven etkinliğinde nasıl düşündüğüne ve yaptığı değişikliklere yönelik görüşme kaydından bir kesit sunulmuştur.

Araştırmacı: Sen Kayan Merdiven etkinliğini ilk çözümünde doğrusal olarak düşünmüşsün. Yani h ne kadar azalıyorsa k o kadar arttyor gibi düşünmüşsün.

ÖA3: Evet ilk çözümümde burada ne kadar azalıyorsa burada da o kadar arttığını düşünmüştüm. Ama sonraki çalışmamda özellikle dinamik animasyon oluşturarak tekrar üzerinde çalıştı̆̆ımızda değişimlerin karelerle ilgili olduğunu fark ettim.

Araştırmacı: Peki bunu bu grafik üzerinde tekrar açılamak ister misin? Dinamik animasyonu da kullanabilirsin.

ÖA3: İz yaptırarak görebiliriz... Veya aralarındaki farkları gözlemleyebilirim. Bir birimde ne kadar artmıs, bir birimde ne kadar azalmış ona bakabiliriz..

Araştırmacl: Yükseklik ve yatay uzaklık mesafelerini ölçtürmüşsün, şimdi yapabilir misin?

ÖA3: Tamam, şimdi sıfirdan başlayalım. Şimdi yükseklik en yüksek değerinde, yatay mesafe 0,06. Yükseklik 6,83. Şimdi yatay mesafeyi l'e getirelim, 1,04'e 6,75. Şimdi 2'ye getirelim. 2,02 ve 6,52. 3' e getirelim, 6,13. Şimdi burada bunun azalmasıly bunun artışını ilişkilendirebiliriz.

Araştırmacl: Evet, 
ÖA3: Șimdi bu 1 birim arttı, bu ise 0,08 birim azaldı. Tekrardan baktı̆̆ımızda yine 1 birim arttı̆̆ında 0,23 azaldı. Şimdi bir sonrakine bakacağız ve muhtemelen daha fazla azalacak. Evet, 6,52 den 6,12 yani 0,40 azaldr. Evet, yani ilk başta bu 1 arttı̆̆ında diğerinin de 1 azalacağını düşünmüştüm, ama gördügü̈müz gibi bunun her 1 birim artışında diğeri artarak azallyor. Yani azalma miktarı gittikçe artıyor...

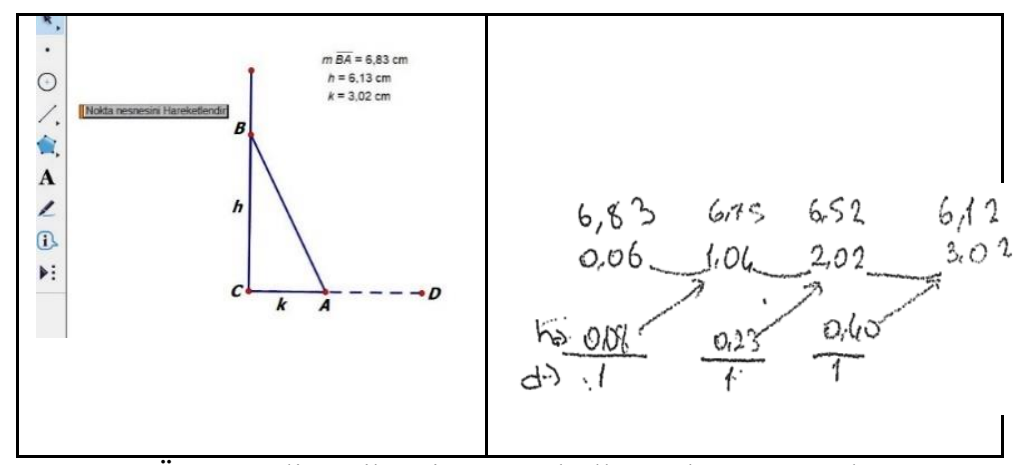

Şekil 2. ÖA3’ün dinamik animasyon kullanarak yaptığı çalışma

Araştırmacı: O zaman artarak azalan grafiği nasıl bir şey?

ÖA3: [Dış bükey bir grafik çiziyor]. Burada h artarak azalıyor, yani daha hızlı azaliyor, $k$ ise sabit miktarda artıyor. Aslında biz burada k'nın artışını sabit tutup h'nin değişimini gözlemledik. Tam tersini de yapabilirdik.

Araştırmacı: Peki bu artarak azalıyor dedin, bu ise sabit miktarda artıyor dedin. İkisi birlikte nasıl değişiyor?

ÖA3: Hmmm... Aslında tersi gibi düşünebiliriz. Yani bu artarak azaliyorsa bu da artarak artıyor veya azalarak artıyor. Bir dakika biraz düşüneyim...[animasyonu hareket ettirip değerleri inceliyor] yani h artarak azaliyor, $k$ ise sabit artıyor. Veya şöyle diyebiliriz, ĕger k'nin sabit miktarda arttı̆̆ını düşünürsek h artarak azaliyor.

Araştırmacı: Peki şu nümerik olarak çalıştığın fikri grafik üzerinde de gösterebilir misin? Yani grafik üzerinde bunlar tam olarak ne anlama geliyor?

ÖA3: [bulduğu değerleri grafik üzerine kabaca işaretliyor ve iç bükey azalan bir grafik çiziyor]. Yani bunu eşit miktarda artırdiğım için, yükseklik değeri gittikçe daha aşăgıya işaretlememiz gerekiyor. Diğer türlü doğrusal bir ilişki olurdu. Yani ardışık iki nokta arasında çizdiğim eğimin gittikçe artması gerekiyor.

ÖA3 kodlu öğretmen adayı, dinamik animasyonlarla çalıștıktan sonra Kayan Merdiven etkinliğindeki grafiğgi iç bükey azalan bir grafik olarak güncellemiş ve bunu da ( $l$ merdivenin uzunluğunu göstermek üzere) $h^{2}+k^{2}=l^{2}$ cebirsel eşitliğine dayandırmıştır. ÖA3 kodlu öğretmen aday1, kâğıt-kalem çözümünde yansıtttı̆g sözel açıklamalarında ise $h^{2}+k^{2}=l^{2}$ cebirsel ifadesine bağlı kalmasına rağmen doğrusal bir grafik oluşturmuş ve kovaryasyonel düşünme öğelerini açık bir şekilde yansıtmamıştır. Dinamik animasyon kullanımı ÖA3'ün verilen durum üzerine tekrardan ve biraz daha ayrıntılı olarak düşünmesini sağlamıştır. Görüşmede bu grafiği daha detaylı açılaması istendiğinde ÖA3, GSP programının veri alma özelliğini kullanarak yerden yükseklik ve yatay uzaklık değerlerini kaydetmiştir. ÖA3 doğrudan ve sistematik koordinasyonu doğru kullanarak yatay uzunluk mesafelerini birer birim artırmış ve karşllık gelen yükseklik değerleri arasındaki farklara bakarak yüksekliğin daha hızlı azaldığını ifade etmiştir. Grafiğin eğriliğini belirlerken tek bir değişkenin (yükseklik) değerlerinin gittikçe daha fazla azaldığını ifade etmesi ÖA3'ün değişim oranını miktar odaklı nicelleştirdiğini göstermektedir. Dinamik animasyonun veri alma özelliği ÖA3'ün doğrudan ve sistematik koordinasyon kullanabilmesine yardımcı olmuştur. Ayrıca, ÖA3'ün değişim oranını (hızını) miktar odaklı nicelleştirebilmesine de olanak sağlamıştır. Aşağıda ÖA3 kodlu öğretmen adayının dinamik animasyonların kendisine ne sağladığına yönelik düşüncelerini yansitan görüşme kaydından bir kesit sunulmuştur.

Araştırmacı: Anladım. Peki, sen önceden neden doğrusal düşünmüş olabilirsin?

ÖA3: Evet, aslında h kare artı k kare eşittir l kare diye bulunca çok kolayca bulmuş hissettim ve üzerine çok ayrıntılı düşünme ihtiyact hissetmedim. Bu bana çok basit gibi geldi ve üzerine düşünmedim çok fazla.

Araştırmacı: Peki bu animasyonu oluşturmak ve onu kullanarak durum üzerine çalışmak sana ne sağladı?

ÖA3: Bu animasyon tek başına değil de şu değerleri anlık olarak hesaplıyor olması işimizi çok kolaylaştırdı. Örneğin biz derslerde a kare artı $b$ kare eşittir c kare formülünü kullaniyoruz ve üzerine çok düşündürtmüyoruz. Bu animasyonda ise bu cebirsel ifadede $a, b$, ve c'nin birlikte nasll değiştiğini anlık olarak hangi nümerik değerleri aldığını gözlemleyebiliyoruz. Yani öğrenciler benim düştüğüm yanılgıya düssebilirler. Yani bu 1 azalırken bu da 1 birim artar gibi... Ama burada değerleri anlık olarak görebildiğimiz için değişimlerin eşit miktarlarda olmadı̆̆ın fark edebilirler.

Araştırmacı: Yani bu tür animasyonlar bir fayda sağlar mı?

ÖA3: Kesinlikle sağlar, dediğim gibi değerleri anlık olarak görmelerini ve değişkenlerle ilgili daha doğru ilişkiler oluşturmalarina katkl sağlar...

Araştırmact: Sadece statik (kâğıt-kalem) ile anlatsak nasıl olur?

ÖA3: Yani tabi yapılabilir, ama bizim burada dinamik olarak gözlemlediğimiz şeyi hayal dünyasında yapmaya çalışacak... Yani burada mesela sonsuz tane veri alabiliyoruz, ama kâğlt kalem ile çözdügümüzde birkaç veri ile çalı̧̧abiliriz. Bir de benim yaptı̆̆ım örnekte olduğu gibi köklü sayı filan çıkıyor. Yani işi biraz daha 
zorlaştırlyor. Burada ise aradaki verilerin hepsini görebiliyor, buda onların düşünmelerine fayda sağlayacaktır.

Yukarıda verilen görüşme kaydında ÖA3 kodlu öğretmen adayı, dinamik geometri yazılımının anlık olarak veri alabilme ve analiz edebilme özelliklerini vurgulayarak Pisagor teoremi eşitliğindeki değişkenlerin birbirleri arasındaki nümerik ilişkiyi daha net görmesine yardımcı olduğunu söylemiştir. ÖA3 kodlu öğretmen adayının ifade ettiği gibi değişkenlere yönelik bazı nümerik değerler kâğıt-kalem ile de elde edilebilir, fakat dinamik geometri yazılımı ortamına göre bunun daha kısıtlı ve zor olduğu aşikârdır. ÖA3, dinamik animasyon ile anlık veri alabilmesi neticesinde nicel operasyonları hızlı bir şekilde gerçekleştirerek değişkenlerin birlikte değişimine daha doğru bir şekilde karar verebilmiştir. Uzay mekiği etkinliğinde ise ÖA3'ün dinamik animasyon ve kâğıtkalem çözümleri aynı kalmıştır. Fakat ÖA3, dinamik animasyonun kendisine değişkenlerin birlikte değişimini nümerik değerlerle daha net görmesini sağladığını ifade etmiştir.

\section{2. ÖA4 Kodlu Öğretmen Adayı}

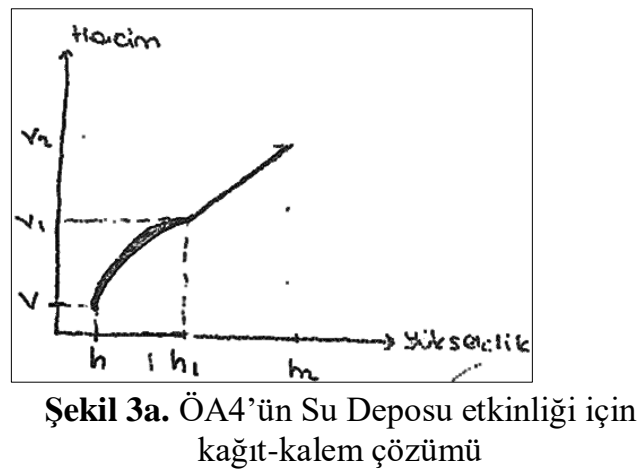

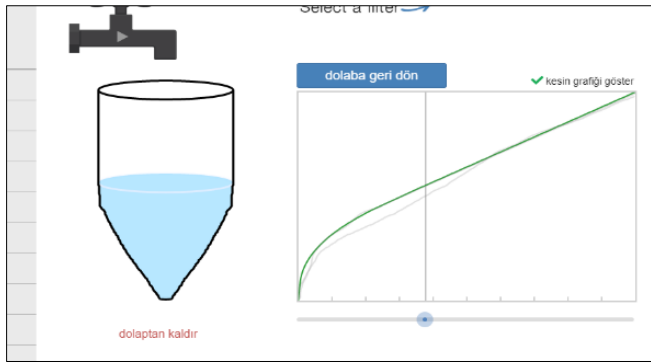

Şekil 3b. ÖA4'ün Su Deposu etkinliği için desmos uygulaması ile çalışmasından bir kesit

Şekil 3a ve Şekil 3b'ye bakıldığında, görüşme yapılan öğretmen adaylarından bir diğeri olan ÖA4 kodlu öğretmen adayının çözümleri incelendiğinde, "Su Deposu" etkinliği için birincil değişkenlerle fakat değişkenlerin rolünü değiştirerek düşündüğü görülmektedir. ÖA4 kodlu öğretmen adayının, grafik üzerinde bağımsız değişkeni yükseklik, bağımlı değişkeni hacim olarak yerleştirmesine karşın sözel açıklamalarında hacme bağlı yükseklik üzerine konuştuğu ve grafiği de buna göre çizdiği görülmüştür. ÖA4’ün değişkenlerin rolünü değiştirerek düşünmesi sözel açıklamalar ile grafik gösterimi arasındaki tutarsızlığa sebep olmuştur. Web tabanlı desmos uygulaması ile etkinlikte verilen depo şekli için dinamik bir grafik üzerine çalışmış ve yukarıdaki grafiği elde etmiştir. Kendi çizdiği grafik ile web ortamında oluşturduğu dinamik grafik arasındaki benzerliği vurgulamış ancak dinamik grafik üzerinde keskin bir geçişin olmamasına şaşırdığını ifade etmiştir. Kâğıt-kalem ile çözümünde diğer katılımcıların çoğunun yaptığı gibi keskin geçişli grafik çizmesi, ÖA4'ün değişim oranını miktar odaklı veya yoğunluk odaklı olarak düşünemediğinin bir göstergesi olarak yorumlanmıştır.

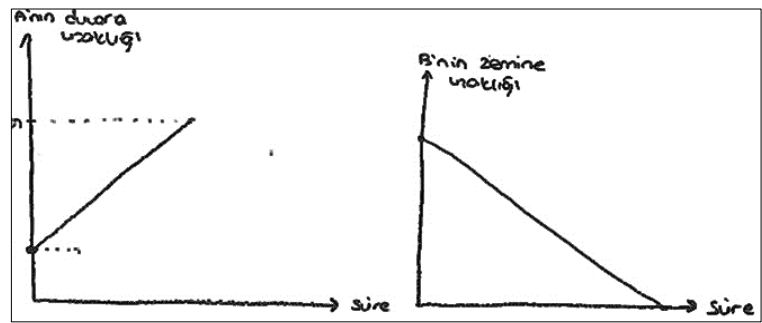

Şekil 4a. ÖA4'ün Kayan Merdiven etkinliğini kâğıtkalem ile çözümü

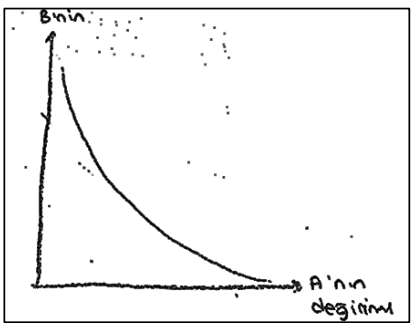

Şekil 4b. ÖA4'ün Dinamik Animasyon sonrasında yeniden çizdiği grafik

Kayan Merdiven etkinliği için ise ÖA4'ün ikincil bir değişken (zaman) ile düşündüğü, dolayısıyla zamana bağlı olarak A noktasının duvara uzaklığını ayrı bir grafik, zamana bağlı B'nin zemine uzaklığını ise başka bir grafik olarak çizdiği görülmektedir (bknz. Şekil 4a). Bu, değişkenleri koordine edememe şeklindeki düşünmenin tipik bir örneğini teşkil etmektedir. ÖA4'ün ilk etapta eş zamanlı ve birlikte değişen nicelikle arasında doğrudan bir ilişki kuramadığı, ikincil bir değişken (zaman) üzerinden düşündüğü görülmektedir. Noktaların uzaklık değişimlerini ise doğrusal olarak düşünmesi, ÖA4'ün değişim oranına (hızına) yönelik kabaca veya sezgisel bir nicelleştirme yaptığının bir göstergesidir.

Kayan merdiven etkinliğinin kâğıt-kalem ile yapılan çözümleri toplandıktan sonra ÖA4, Şekil 5a'da görülen GSP programı ile dinamik animasyonu oluşturmuştur. Bu animasyonu oluşturduktan sonra ÖA4 ilk olarak kâğıtkalem çözümüne geri dönmüş ve yükseklik ile yatay uzunluk arasındaki ilişkinin grafiğini Şekil 4bb deki gibi güncellemiştir. Yeni oluşturduğu grafikte ÖA4'ün zaman değişkenini kullanmadan birincil değişkenlerle ve doğrudan koordinasyon yaparak düşünmeye başladığı görülmektedir. 


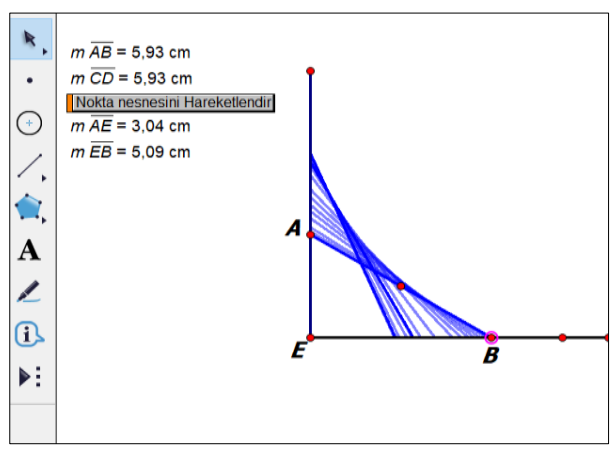

Şekil 5a. ÖA4’ün Kayan Merdiven için oluşturduğu animasyon

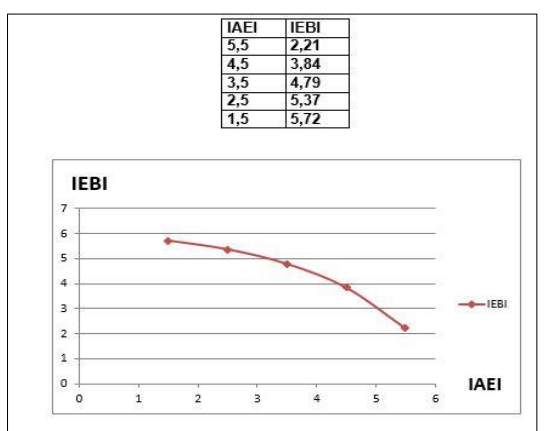

Şekil 5b. ÖA4’ün Dinamik animasyon ile yaptığ 1 çalışma

ÖA4 kayan bir merdiven animasyonunu kullanarak merdivenin uç noktasının yerden yüksekliğini $|A E|$ olarak, diğer ucunun duvara uzaklığını ise $|E B|$ olarak göstermiş ve GSP programının özelliklerini kullanarak bu uzunlukların anlık değerlerini hesaplatmıştır. Daha sonra, bu uzunlukların anlık değerlerini MsExcel elektronik tablolama programına kaydederek Şekil 5b'de görülen grafiği elde etmiştir. ÖA4'ün kâğıt-kalem ile yaptığ çözüm ile kıyaslandığında, etkinlik bağlamında verilen birincil değişkenlerle, doğrudan ve sistematik koordinasyon kullanarak düşünmeye başladığı görülmektedir. ÖA4 daha sonra, $|A E|$ değerlerini eşit miktarlarda (1'er birim) azaltarak karşılık gelen $|E B|$ değerlerini hesaplatarak kaydetmiştir. Burada değişkenlerin doğrudan ve sistematik koordinasyonu açık şekilde görülmektedir. Bunun sonucunda ÖA4, Şekil 5b'de görülen grafiği elde etmiş fakat MsExcel ile elde ettiği bu grafiğin eğriliğini açıklamakta zorlanmıştır. Aşağıda ÖA4 kodlu öğretmen adayının Kayan Merdiven etkinliğinde dinamik animasyon ile nasıl düşündüğüne yönelik görüşme kaydından bir kesit sunulmuştur.

Araştırmacı: Evet, ilk çizdiğin grafikte zamana bağlı olarak düşünmüştün [Şekil 4a'da görülen doğrusal grafikler].

ÖA4: Evet aslında ben ilk çizdiğimde zamana bağlı düşündüm. Yani bir ucunun yüksekliği zamana bağlı azalırken, diğer ucunun duvara uzakliğl zamana bağlı olarak artmaktadır.

Araştırmacı: Neden bu şekilde doğrusal olarak düşündün?

ÖA4: Aslında çok fazla düşünmedim üzerine, yani biri azalırken diğeri artar diye düşündüm.

Araștırmacı: Daha sonra grafiği değiştirdin [Şekil 4b'de görülen dış bükey grafik]. Neden?

ÖA4: Evet, GSP'de animasyonu oluşturunca yükseklik ile uzaklığın sabit bir eğimde değişmediğini hissettim. Merdiven aşağı doğru kaydıkça dışbükey bir görüntü oluşuyor [Şekil 5a]

Araştırmact: Bu ne anlama geliyor?

ÖA4: Ĕ̆im gittikçe azallyor... Yani yükseklikteki değişimin yatay uzunluktaki değişime oranı gittikçe azalıyor.

Araştırmacı: Peki MsExcel ile bu grafiği elde ettin [iç bükey azalan bir grafik] Bunu nasıl değerlendiriyorsun? Bu grafik hakkında ne düşünüyorsun?

ÖA4: [Bir süre inceliyor]. Şu an bilmiyorum, Excel de bu grafik çıkınca da şaşırmıştım... Evet, yani eğiminin gittikçe azaldığını düşünerek bu dış bükey grafiği çizdim ve halen öyle olması gerektiğini düşünüyorum. Ama burada eğim gittikçe artıyor. Şu an kafam çok karıştı...

ÖA4 kodlu öğretmen adayı, kâğıt-kalem çözümünde bu iki değişkeni zamana bağlı ayrı birer grafik olarak düşündüğünü ve doğrudan ilişkilendiremediğini belirtmiştir. ÖA4 doğrusal olarak çizmesinin sebebi olarak ise üzerinde çok düşünmediğini belirtmiştir. ÖA4 kodlu öğretmen adayı, dinamik animasyon oluşturduğunda ilk olarak yükseklik ve uzaklık değişkenlerini doğrudan ilişkilendirerek Şekil 4b'de görülen dişbükey azalan grafiği çizdiğini ifade etmiştir. Öğretmen adayı, grafiği dışbükey azalan çizmesinin sebebi olarak ise dinamik animasyonda sezgisel olarak öyle göründüğünü söylemiştir. ÖA4, animasyondan elde ettiği verileri kullanarak MsExcel yardımıyla oluşturduğu Şekil 5b'de görülen grafiğin içbükey olmasına ise şaşırdığını ve halen bunun sebebini algılamakta zorlandığını ifade etmiştir. Görüşmenin devamında, ÖA4 kodlu öğretmen adayından MsExcel ile oluşturduğu grafiği açıklaması istenmiştir.

Araştırmacı: Evet ÖA4, şu iç bükey ve dışbükey çizdiğin grafikler arasındaki farka biraz daha bakıp açıklayabilir misin?

ÖA4: [Düşünüyor]... Verilerimizle alakalı olabilir diye düşünüyorum. Aslında burada kafamdan çizdim ama verileri kullanınca bu iç-bükey grafik çıkıyor.

Araştırmacı: Peki bunu nasıl açıklayabilirsin?

ÖA4: Valla anlamaya çalışıyorum hocam [düşünüyor]. Burada kafamızda kurduğumuz durumda hipotenüsü ve diğer değerleri net bir şekilde bilmediğimiz için böyle bir şey diye düşünüyoruz ama gerçek Excel de de net bir şekilde de görülüyor ki böyle.

Araştırmacı: O zaman teknoloji veya animasyon oluşturmak sana nasıl bir fayda sağladı, bu etkinlik için mesela?

ÖA4: Bu etkinlik için teknoloji yanlış düşündüğ̈̈müzü gösterdi. Yani veri topladık, gerçek değerlerle bir grafik oluşturduk filan, ama öbür durumda kafadan yaklaşık bir grafik düşünüyoruz. Yani şaşırdım doğrusu, benim 
hayal ettiğimden çok farklı bir grafik çıktı karşıma... Yani merdivenin kayma hareketine bakınca benim ilk çizdiğim gibi olması gerektiğini hissediyorum. Yani gerçekten şu an farklı bir şey düşünemiyorum şu anda.

Yukarıda verilen görüşme kaydında görüldüğü üzere ÖA4 kodlu öğretmen adayı, grafiğin neden iç bükey azalan olması gerektiğine ikna edici bir açıklama getirmekte zorlanmıştır. İki değişkenin birlikte değişimini koordine etmeye çalışması ve dış bükey azalan bir grafik çizmesi, dinamik animasyonun ÖA4'ün en azından birincil değişkenlerle düşünmesini sağladığını göstermektedir. ÖA4, doğrudan ve sistematik koordinasyon kullanarak değişkenlerin değerlerini anlık olarak olanak hesaplamış ve MsExcel kullanarak grafiğe ulaşmıştır. Fakat bu grafiği açıklamakta zorlanması, ÖA4'ün doğrudan ve sistematik koordinasyon becerisini zihinden yapamadığını göstermektedir. Benzer șekilde, öğretmen adayı değișim oranının (hızının) nicelleștirmesini miktar odaklı veya yoğunluk odaklı olarak değil de, kabaca ve sezgisel olarak yapmaya devam etmiştir. Dolayısıyla teknoloji ve animasyon kullanımı ÖA4 için zihinsel yükü hafifletici bir araç rolü oynamıştır. Uzay mekiği etkinliğinin kâğıt-kalem çözümünde ise ÖA4 birincil değişkenlerle düşünmüş, doğrudan koordinasyon kullanmış ve değişim oranını yine kabaca nicelleştirmiştir. Uzay Mekiği etkinliğinde ÖA4 dinamik animasyonu kullanarak veri toplamış ve doğrudan ve sistematik koordinasyonu ilk defa doğru bir şekilde kullanarak dışbükey artan bir grafiği açıklayabilmiştir. Dinamik animasyon kullanımı ÖA4 için Kayan Merdiven etkinliğinde zihinsel yükünü hafifleten bir araç iken Uzay Mekiği etkinliğinde ise doğrudan ve sistematik koordinasyonu kullanabilmesine olanak sağlamıştır.

\section{3. ÖA6 Kodlu Öğretmen Adayı}

ÖA6 kodlu öğretmen adayının farklı etkinliklerdeki düşünme süreci incelendiğinde, Su Deposu etkinliğinde birincil değişkenlerle düşündüğü ve değişkenleri doğrudan koordine edebildiği görülmektedir (bkz. Şekil 6-a). Fakat grafiğe yönelik sözel açıklaması ve doğrusal bir grafik çizmesi, ÖA6'nın değişim oranına yönelik sezgisel veya kabaca bir nicelleştirme yaptığını göstermektedir. Aşağıda Şekil-6-a-b-c'de görüldüğü üzere ÖA6 kodlu öğretmen adayı diğer etkinlikler için de grafikleri doğrusal olarak çizmiştir. Yani ÖA6 her etkinlikte birincil değişkenlerle düşünmüş, değişkenleri doğrudan koordine etmiş fakat değişim oranını kabaca veya sezgisel olarak nicelleştirmiştir.

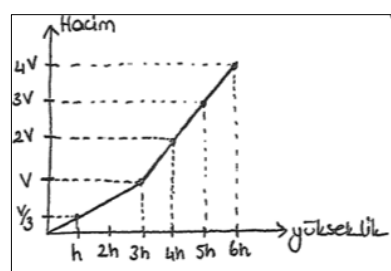

Şekil 6-a. ÖA6'nın Su

Deposu için kağıt-kalem çözümü

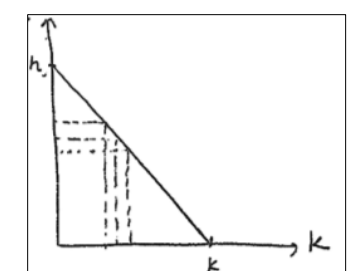

Şekil 6-b. ÖA6'nınKayan Merdiven için kağıt-kalem çözümü

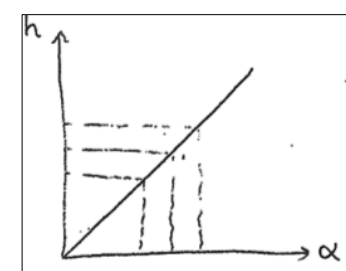

Şekil 6-c. ÖA6'nın

Uzay Mekiği için kağitkalem çözümü

Dinamik animasyonlar oluşturduktan sonra ÖA6, Su Deposu etkinliğinde ilk kısım için artarak artan bir grafik, geçiş noktasında keskin bir geçiş yaparak ikinci kısım için ise doğrusal bir grafik oluşturmuştur. ÖA6 kodlu öğretmen adayı Kayan Merdiven etkinliğinde ise dinamik animasyonu oluşturabilmiş fakat grafikte bir değişikliğe gitmeden yine doğrusal olması gerektiğini ifade etmiştir. ÖA6 Kayan Merdiven için dinamik animasyon oluşturmasına rağmen veri alma özelliğini kullanmadan sadece animasyonu izleyerek karar vermiştir.

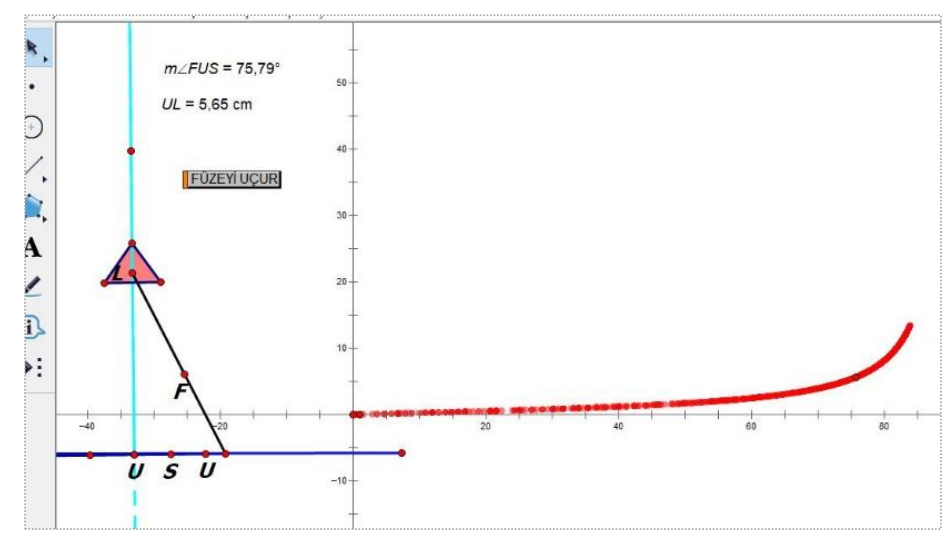

Şekil-7. ÖA6’ın Uzay Mekiği için oluşturduğu dinamik animasyon

ÖA6, Uzay Mekiği etkinliğinde ise kâğıt-kalem ile doğrusal çizdiği grafiği dış-bükey artan bir grafik olarak güncellemiştir (bkz. Şekil-7). ÖA6 bu etkinlik için oluşturduğu dinamik animasyonda nokta izleme özelliğini 
kullanarak Şekil-7'deki açıya bağlı yükseklik değişim grafiğini elde etmiştir. Aşağıda ÖA6 kodlu öğretmen adayının Uzay Mekiği etkinliğinde nasıl düşündüğüne yönelik görüşme kaydından bir kesit sunulmuştur.
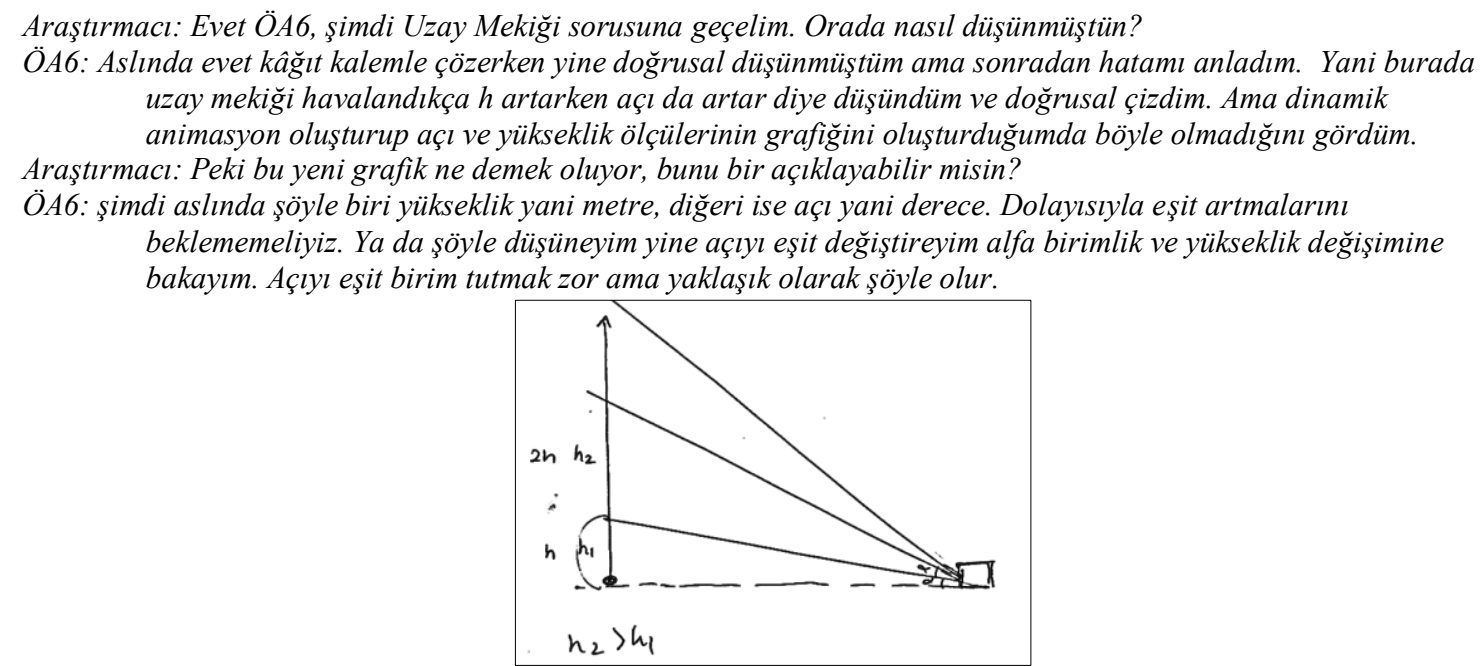

Şekil 8. ÖA6'nın Uzay Mekiği için görüşme esnasında yaptığı bir çizim

Araştırmacı: Tamam ne gözlemliyorsun?

ÖA6: Hmm, evet açı gittikçe daha fazla artıyor. Bariz bir şekilde görünüyor. Hatta bir alfa daha yaparsak yükseklik artışının daha fazla olduğunu görebiliyoruz.

Araştırmacı: Peki bunu grafiğe aktarırsak ne demek oluyor?

ÖA6: Grafiğe aktarırsak ne olacak, yine alfayı eşit miktarlarda artırırsak... Mesela buraya h dersek burası 3h olacak örneğin. Yani h gittikçe daha fazla artıyor. Artarak artan bir grafik oluyor.

Araștırmacı: Peki ÖA6, son olarak bu dinamik animasyonlar sana bir fayda sağladı mı?

ÖA6: Aslında sağlayabilirmiş, çok düz ve yüzeysel baktığımı anladım. Yani aslında animasyonlarda kayan merdivende de verilere de bakarak daha detaylı düşünebilirmişim. Veri oluşturmayı düşünmemişim mesela...

Araştırmacı: Peki dinamik animasyonlar sınıflarda başka nasıl kullanılabilir?

ÖA6: Bence böyle şeyler gerekiyor çünkü bir öğrenciye şu grafiği direk çizip vermektense burada dinamik olarak kendisinin görmesi daha iyi. Yani füzeyi uçurabiliyoruz ve aynı zamanda istediğimiz grafiği çizdirebiliyoruz, bu daha akılda kalıcı bir şey olur. Öğrencilerin anlamasını daha da kolaylaştırır diye düşünüyorum.

ÖA6 kodlu öğretmen adayı ile yapılan görüşme kaydına bakıldığında, öğretmen adayının kâğıt-kalem çözümlerinde doğrusal düşündüğü ve değişkenlerin birbiriyle ilişkili değişimi üzerine çok detaylı düşünmediği anlaşılmaktadır. ÖA6 birincil değişkenlerle düşünmesine rağmen doğrudan ve sistematik koordinasyonu kullanmamış ve değişim oranını (hızını) kabaca veya sezgisel olarak nicelleştirmiştir. Dinamik programların veri toplama ve grafik çizdirme gibi özelliklerini kullanmadan sadece animasyon oluşturmanın, ÖA6'nın düşünme biçimi üzerine çok az etkisinin olduğu görülmektedir. ÖA6 kodlu öğretmen adayı dinamik geometri yazılımının veri toplama ve grafik çizdirme özelliğini en son uygulanan Uzay Mekiği etkinliğinde kullanabilmiştir. Uzay Mekiği etkinliğinde ÖA6 dinamik geometri yazılımıyla farklı bir grafik elde ettikten sonra kâğıt-kalem grafiğgi üzerine tekrar düşünme ihtiyacı hissetmiştir. ÖA6 kodlu öğretmen adayı değişkenleri koordine ederken açı değerlerini eşit miktarlarda artırıp yükseklik değişimlerine bakarak ilk defa doğrudan ve sistematik koordinasyonu kullanmıştır. Görüşme esnasında ÖA6 kodlu öğretmen adayından Kayan Merdiven etkinliği için de dinamik bir grafik oluşturması istenmiştir. ÖA6 nokta izleme özelliği ile iç bükey azalan bir grafik elde etmiş, fakat bu grafiği yorumlayarak doğrulamakta oldukça zorlanmıştır. Dinamik animasyonların düşünme becerisi üzerinde faydasının olup olmadığı sorusuna ise diğer öğretmen adayları gibi ÖA6 da dinamik geometri yazılımı ile veri toplama ve inceleyebilme özelliğinin önemini vurgulamış ve dinamik animasyonların anlık veri sağlaması bakımından çok kullanışlı olabileceğini fark etmiştir.

\section{4. ÖA11 Kodlu Öğretmen Adayı}

ÖA11 kodlu öğretmen adayı ise Su Deposu etkinliği için birincil değişkenlerle fakat değişkenlerin rolünü değiştirerek düşünmüş ve değişkenleri doğrudan koordine edebilmiştir (bkz. Şekil 9-a). Yüksekliğe bağlı hacim grafiğinde ÖA11, deponun her iki kısmı için doğrusal bir grafik oluşturmuştur. Bu durum ÖA11'in değişim oranına yönelik kabaca veya sezgisel bir nicelleştirme yaptığının bir göstergesi olarak yorumlanmıştır. Şekil 9b'de görüldüğü üzere ÖA11 Kayan Merdiven etkinliğinde tamamen cebirsel ifadeye bağlı kalarak çeyrek çember grafiği oluşturmuştur. Fakat ( $r$ merdivenin uzunluğunu göstermek üzere) $x^{2}+y^{2}=r^{2}$ cebirsel eşitliğini kullanarak grafiği oluşturmuş ve sözel açıklamalarında cebirsel ifadenin grafiğine bağlı kaldığından kovaryasyonel düşünme öğelerini açık bir şekilde yansıtmamıştır. Uzay Mekiği etkinliğinde ise ÖA11 sadece sözel ifade ile açıklama yapmış ve yükseklik ile açının doğru orantılı bir şekilde değişeceğini ifade etmiştir (bkz. 
Şekil 9-c). Yani ÖA11, Su Deposu ve Uzay Mekiği etkinliklerinde birincil değişkenlerle düşünmüş, değişkenleri bazen doğrudan koordine edebilmiş veya edememiş, değişim oranını ise sezgisel olarak nicelleştirmiştir.

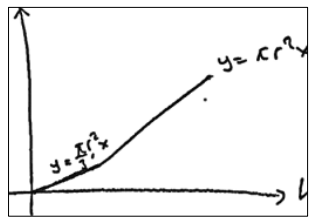

Şekil 9-a. ÖA11'in

Su Deposu için kağıt-

kalem çözümü

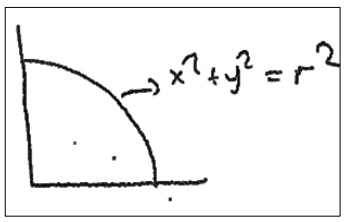

Şekil 9-b. ÖA11'in

Kayan Merdiven için kağıt-kalem çözümü

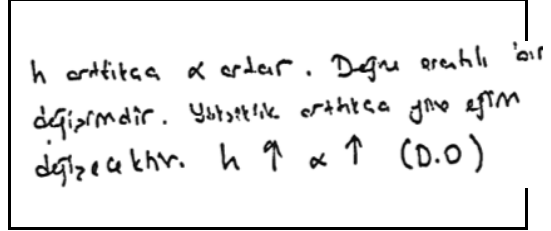

Şekil 9-c. ÖA11'in Uzay Mekiği

için kağıt-kalem çözümü

Dinamik animasyonlar oluşturduktan sonra ÖA11 Su Deposu etkinliği ile birincil değişkenlerle düşünmeye başlamış ve deponun alt kısmı için artarak artan bir grafik, ikinci kısmı için ise doğrusal bir grafik oluşturmuştur. ÖA11 koniden silindire geçiş noktasını grafik üzerinde keskin bir kırılma noktası olarak çizmiştir. Kayan merdiven etkinliğinde ise ÖA11 cebirsel ifadeye bağlı kalarak oluşturduğu grafikten emin olduğundan dolayı dinamik animasyon oluşturduktan sonra durum üzerine bir sözel açılama gereği duymamış ve grafikte de bir değişikliğe gitmemiştir. Uzay mekiği etkinliğinde de ÖA11 kâğıt-kalem çözümünde olduğu gibi dinamik animasyonu oluşturduktan sonra sadece sözel açıklama yapmış ve açı ile yüksekliğin doğru orantılı olarak değişeceğini ifade etmiştir. Aşağıda ÖA11 kodlu öğretmen adayının Uzay Mekiği etkinliğinde nasıl düşündüğüne yönelik görüşme kaydından bir kesit sunulmuştur.

Araştırmacı: Peki Uzay Mekiği sorusu hakkında nasıl düşündün? Kăğıt-kalem çözümünde bir grafik göremiyorum, sadece sözel açıklama yapmışsın.

ÖA11: Evet, grafik çizmedim. Şöyle, uzay mekiği çıktıkça kameranın açısı artıyor. Bundan dolayı doğru orantılı dedim. Ama burada ĕgim gittikçe artiyor...

Araştırmacı: Animasyona bakalım istersen ... Yani grafik oluştursan nasıl bir grafik ortaya çıkar? Açı ile yükseklik birlikte nasil değișiyor diye soruyordu.

ÖA11: Evet grafik çizmemiştim, ikisi de artacak... Burada şimdi zemin sabit kaltyor bir üçgen olarak düşünürsek. Yani işte ona doğru orantılı dedim, açı arttıkça yükseklik te artıyor...

Araştırmact: Doğru orantı ne demek?

ÖA11: Biri arttıkça diğeri de artıyor anlamında...

Araştırmacı: Peki doğrusal mi?

ÖA11: Doğrusal değil, yükseklik hep artacak, dolayısıyla açı da hep artacak. Yine parabolik bir şey olması gerekiyor yani... Yani bire-bir değil, parabolik bir şekilde artacak çünkü eğim sürekli değişiyor. İçbükey ya da dışbükey artan olabilir.

Araștırmacı: Peki hangisi olur? Dinamik animasyona da bakabilirsin tekrar...

ÖA11: [Dinamik animasyonu inceliyor] ben açı değerlerini ölçtürmemişim. Onu ölçeyim, evet şu anda açı 45 derece ve yükseklik ise 7,57 görünüyor (birkaç değer daha bakıyor). Açı çok artarken, yükseklik daha az artıyor..

Araştırmacı: Açı çok artarken yükseklik daha az artacak, buna tam olarak nasıl karar verdin?

ÖA11: [Animasyonu inceliyor] evet açı çok artarken yükseklik daha az artıyor.

Şekil 9-c'de ve yukarıdaki görüşme kaydından alınan kesitte görüldüğü üzere ÖA11, açı ve yükseklik değerlerinin her ikisinin de artmasını doğru orantılı değişim olarak nitelendirmektedir. Fakat grafiğin doğrusal olmayacağını belirtmesi ÖA11'in doğru orantı kavramı ile ilgili kavram yanılgısı olabileceğini göstermektedir. Açı ve yüksseklik değerlerini anlık olarak ölçtürerek dinamik animasyonu tekrar izlediğinde "açı çok artarken, yükseklik daha az artıyor" şeklindeki sözel ifadesi ÖA11'in açı ve yükseklik değişkenlerin birlikte değişimini koordine etmeden açıyı ayrı, yüksekliği ayrı birer değişken olarak düşündüğünü göstermektedir. ÖA11'in diğer etkinliklerde de değişkenleri grafik üzerine doğru yerleştirmesine rağmen sözel açılamalarında değişkenleri doğrudan koordine etmekte zorlandığı görülmüştür. Görüşmenin devamında ÖA11, ancak araştırmacının ipucu vermesi sonucunda değişkenleri doğrudan ve sistematik koordine edebilme fikrini kullanabilmiştir.

Araştırmacı: İstersen bazı değerleri kaydedelim. Örneğin açı 36 dereceyken yükseklik 5,47, açı değerlerini eşit miktarlarda artırsak ne oluyor?

ÖA11: Hmm, tamam, açı değerlerini eşit miktar artıralım. 36 iken 5,47; 45 olduğunda yükseklik 7,40 oldu, bir dokuz birim daha artıralım, 54 olduğunda yükseklik 10,15 oldu, 63 olduğunda ise 14,33 oldu...

Araştırmacı: Burada ne gözlemliyorsun?

ÖA11: Bunları hep 9'ar artırdık, burada yaklaşık 2 birimlik arttı, sonra 3 birim kadar (tam üç değil ama), burada 4 birim kadar arttı. Hım tamam, yükseklik daha çok arttı o zaman. 


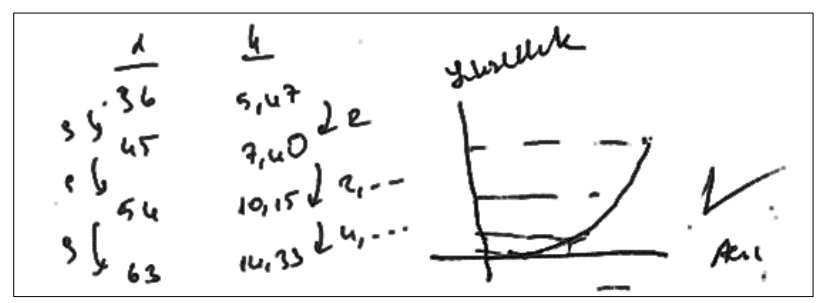

Şekil 10: ÖA11'in görüşme esnasında Uzay Mekiği için yaptığı çalışma

Araştırmacı: Evet ÖA11, bu ne demek oluyor şimdi?

ÖA11: Yani burada açıları sabit aralıklarla değiştirdiğimde yüksseklik giderek daha fazla artıyor. Benim çizdiğgim grafikte azalarak gidiyordu, o zaman grafiğimiz şöyle (Dış bükey artan) bir şey oluyor galiba.

Araştırmacl: Peki ÖA11, o zaman dinamik animasyon net bir fikir vermedi diyebilir miyiz?

ÖA11: Evet, animasyonu izleyince yanlış düşünmüşüm ama açıyı hesaplatıp değerlere bakınca işe yaradı. Yani yükseklik ve eğimi de hesaplatmıştım ama açıy hesaplatmak aklıma gelmedi. Aslında değerleri bu şekilde incelemek aklıma gelseydi baya faydalı olabilirmiş.

Doğrudan ve sistematik koordinasyon yapabilme üst düzey kovaryasyonel düşünme becerisinin önemli göstergelerinden birisidir. ÖA11'in düşünme biçimi incelendiğinde, araştırmacı tarafindan ipucu olarak verilen değişkenlerden birisini eşit miktarlarda değiştirme fikrine kadar değişkenleri doğrudan koordine edemediği veya dolaylı koordine etmeye çalıştığı görülmüştür. Yukarıda verilen görüşme kaydında ÖA11'in, değişkenlerden birisini sabit miktarlarda değiştirme fikrini Uzay Mekiği bağlamında etkili bir şekilde kullanabildiği görülmektedir. Şekil 10'da görüldüğü üzere ÖA11 dinamik animasyon ile birkaç veri toplayıp değişkenlerin birbirleriyle ilişkili olarak nasıl değiştiğini açıklayabilmiştir. Dinamik animasyonun faydası sorulduğunda ise ÖA11 elde edilen anlık değerleri bu şekilde (doğrudan ve sistematik koordinasyon ile) incelemek için faydalı olduğunu ve kendisinin bunu görüşme esnasında fark ettiğini ifade etmiştir. Dinamik animasyon kullanımının, anlık veri toplama ve grafik çizdirme gibi özelliklerini kullanmadığından dolayı başlangıçta ÖA11'in matematiksel düşünme sürecine bir katkısı olmadığı görülmektedir.

\section{Tartışma ve Sonuç}

Öğretmen adaylarının verilen etkinliklere kâğıt-kalem ile yaptıkları çözümlerde sergiledikleri düşünme biçimleri alan yazındaki öğretmen, öğretmen adayı veya farklı seviyelerden öğrenci gruplarıyla yapılan çalışmaların sonuçlarıyla birçok açıdan tutarlılık göstermektedir. İlk olarak, alan yazında birçok çalışmada da gözlemlendiği gibi öğretmen adaylarının birçoğu kağıt-kalem çözümlerinde ikincil değişkenlerle düşünmüştür (ör., Carlson ve ark., 2002; Johnson, 2012; Kertil, 2014; Kertil ve ark., 2019; Stalvey \& Vidakovic, 2015; ŞenZeytun ve ark., 2010). Üniversite öğrencileri ve ortaöğretim düzeyindeki öğrencilerle yapılan çalışmalarda gözlemlendiği gibi, bu çalışmada da öğretmen adayları kâğıt-kalem çözümlerde hacim-yükseklik, açı-yükseklik gibi eş zamanlı değişen değişkenlerin her ikisini de zamana bağlı olarak düşünme eğilimi göstermişlerdir (Johnson, 2012; Keene, 2007; Stalvey \& Vidakovic, 2015). Burada zaman gibi ikincil değişkenlerle düşünmenin yanlış olması değil kovaryasyonel düşünmenin sonraki adımlarında bazı zorluklara sebep olması söz konusudur. Üniversite öğrencilerinde, öğretmen adaylarında ve hatta öğretmenlerde benzer düşünme eğiliminin görülmesi kovaryasyonel düşünme becerisinin ilköğretimden itibaren hiçbir eğitim kademesinde yeterince vurgulanmadığının bir göstergesi olarak yorumlanabilir. Ayrıca, öğretmen adaylarında ki zamana bağlı düşünme eğilimi, fonksiyonların gerçek hayat yorumlarının öğretiminde genellikle zamanın bağımsız değişken olarak kullanımının doğal bir sonucu olabilir (Herbert \& Pierce, 2011, 2012; Jones, 2017; Kertil ve ark., 2019). Öte yandan, Tablo 2'de görüldügü üzere dinamik animasyonlar ile yapılan çalışmalar sonrasında ikincil değişkenlerle düşünmenin çok azalması, öğrencileri birincil değişkenlerle düşünmeye yönlendirme bakımından teknolojinin faydalı olabileceğini göstermektedir.

Değişkenlerin koordine edilme şekline bakıldığında ise doğrudan ve sistematik koordinasyonun çok az kullanılabildiği bulgusu yine benzer çalışmaların sonuçlarıyla tutarlıdır (ör., Carlson ve ark., 2002). Bu ikincil değişkenler düşünmenin bir sonucu olabileceği gibi öğrencilerin fonksiyon kavramını değişkenlerin dinamik değişimi olarak değil de birebir eşleme odaklı öğrenmesinden kaynaklı olabilir (Carlson ve ark., 2003; Hoffkamp, 2011; Monk, 1992). Dinamik değişimlere odaklanmada ve iki değişkenin birlikte değişimini incelemede doğrudan ve sistematik koordinasyon kritik öneme sahiptir ve üst düzey kovaryasyonel düşünme becerisinin en önemli göstergesidir. Bu düşünme şeklini kullanabilen öğrenciler problem durumlarını daha iyi kavramakta, grafikleri daha doğru okuyabilmekte ve sözel olarak ifade edebilmektedir. Bu çalışmada da görüldüğü üzere öğretmen adaylarının çok azı bu düşünme şeklini kullanabilmektedir. Fakat farklı etkinlik ve uygulamalarla üzerinde durulduğunda ve sürekli vurgulandığında en azından sistematik ve doğrudan koordinasyon becerisinin geliştirilebilir bir beceri olduğu görülmektedir. Örneğin, ÖA6 ve ÖA11 kodlu öğretmen adayları ilk başlarda bu beceriyi kullanmazken sonraki süreçte dinamik animasyonlarla beraber kullanabilmişlerdir. 
Birincil veya ikincil değişkenlerle düşünme ve sonrasında değişkenleri koordine etme biçimi değişim oranını (hızını) nicelleştirme şeklini de etkilemektedir. Bu çalışmada öğretmen adaylarının, iki değişkenin birlikte değişimini grafik üzerinde, sözel, nümerik veya cebirsel olarak açıklarken değişim oranına değinmedikleri, bükeyliği belirlerken kabaca nicelleştirmeyi sıklıkla kullandıkları görülmüştür. Doğrudan koordinasyon veya doğrudan sistematik koordinasyon kullanabilen öğretmen adaylarının ise miktar odaklı nicelleştirme yapabildikleri gözlemlenmiştir. Yoğunluk odaklı nicelleştirme çok daha az gözlemlenmiştir. Kertil ve arkadaşlarının (2019) çalışmasında da değinildiği gibi, birincil değişkenlerle düşünme ile doğrudan ve sistematik koordinasyon kullanımı değişim oranının miktar odaklı veya yoğunluk odaklı olarak nicelleştirilebilmesini garanti etmemektedir. Doğrudan ve sistematik koordinasyon kovaryasyonel düşünme becerisinin önemli göstergelerinden biri olsa da Kayan Merdiven etkinliğinde görüldüğü üzere uygun bir nicel operasyon kullanımı kritik öneme sahiptir. Niceliksel düşünme teorisine göre, nicel operasyonlar bilgisi matematiksel kavramların farklı gerçek hayat bağlamlarında anlamlandırılabilmesi ile ilgilidir (Thompson, 1994, 2011). Yani, kovaryasyonel düşünmenin değişim oranını nicelleştirme aşamasında niceliksel düşünme gerekmektedir. Öğrenciler bağımsız değişkenin birim değişiminde bağımlı değişkenin nasıl değiştiğini görebilmeleri için nümerik bir operasyona (Bazı değerler hesaplayabilecekleri bir matematiksel işleme) ihtiyaç duymaktadırlar. Eğer uygun bir nicel operasyon ve sonrasında nümerik bir operasyon kullanımı olmazsa değişim oranını nicelleştirmede nihai hedefe ulaşmakta zorlanmaktadırlar. Bu çalışmada gözlemlenen değişim oranının sezgisel ve kabaca nicelleştirilmesi öğretmen adaylarındaki niceliksel düşünme becerisinin eksikliği ile ilgili olabilir. Öğrencilere niceliksel düşünme ve uygulama becerilerinin kazandırılması da öğretim sürecinde bağlam temelli uygulamaların kullanım sıklığına bağlıdır (Thompson, 2011). Dolayısıyla öğretmen adaylarının kovaryasyonel düşünme becerilerinin geliştirilmesi için farklı bağlamlardan dinamik değişim içeren daha fazla problem çözme deneyimine ihtiyaçlarının olduğu sonucu çıkarılabilir.

$\mathrm{Bu}$ çalışmada, sadece bilgisayar destekli dinamik geometri yazılımları ile dinamik animasyon oluşturmanın ve onu izlemenin öğretmen adaylarının kâğıt-kalem çözümlerine etkisinin minimum düzeyde olduğu görülmüştür. Çalışmanın odağı olmamakla birlikte bu sonuç, literatürde bahsedilen dinamik geometri yazılımlarının ve bilgisayar cebir sistemlerinin derslerde basit düzeyde kullanımın öğrencilerin öğrenmeleri üzerine fazla etkisinin olmadığı sonucunu doğrulamaktadır (Donevska-Todorova, 2018). Dinamik animasyonlar veri alma ve grafik çizdirme gibi özellikleri ile birlikte kullanıldığında, öncelikle kovaryasyonel düşünmede zorluklara sebep olan ikincil değişkenlerle düşünmeyi en aza indirgediği görülmektedir. Öğretmen adaylarının, doğrudan koordinasyon veya doğrudan sistematik koordinasyonu daha kolay yapabilir hale geldikleri görülmüştür. Bazı öğretmen adayları, kâğıt-kalem çözümleri ile dinamik animasyon destekli çözüm arasındaki fark üzerine tekrar düşünme ihtiyacı hissetmişlerdir. Bu anlamda dinamik animasyonlar, öğretmen adaylarının düşünme biçimlerini tekrar gözden geçirmelerini sağlayarak farklı boyutlarda kovaryasyonel düşünmeyi destekleyici bir unsur olmuştur. Öğretmen adaylarında bazıları için ise dinamik animasyonlar, kovaryasyonel düşünme becerilerini geliştirmeden daha ziyade onların zihinsel yükünü hafifletmiş ve derin düşünme ihtiyacını ortadan kaldırmıştır. Bu durumda dinamik animasyonlar öğretmen adayları için çözüme odaklı ve düşünme becerisine bir katkısı olmayan bir araç rolünü almıştır. Teknoloji ve dinamik programların veri toplama özelliği kullanılarak kovaryasyonel düşünme becerileri desteklenebilir (Zbiek, Heid, Blume \& Dick, 2007). Burada öğretmenin öğrencileri teknoloji ile elde ettikleri sonuçların ne anlama geldiğini sorgulaması ve öğrencileri durum üzerinde düşünmeye zorlaması önemli görünmektedir. Bazı öğrenciler için teknoloji kullanarak elde edilen sonuçlar durum üzerinde tekrar ve derinlemesine düşünmeyi sağlama bakımından öğretmenin yönlendirmesine ihtiyaç olmadan kendiliğinden tetikleyici bir unsur olabilmekte fakat her öğrenci için bu söz konusu değildir. Teknoloji kullanımının faydalı olabilmesi için öğretmenin durum üzerine sorgulama yapması en azından bazı öğrenciler için gerekli görünmektedir.

\section{5. Öneriler}

Son olarak bu çalışma alan yazındaki çalışmalarla tutarlılık gösterse de elde edilen bulgular çalışmada kullanılan etkinlikler ve çalışmanın katılıcıları ile sınırlıdır. Nitekim Johnson ve arkadaşları (2017) tarafından yapılan çalışmada kullanılan etkinliklerin doğasına göre öğrencilerin farlı kovaryasyonel düşünme biçimlerini ortaya koyabildikleri ve bir etkinlik bağlamında gösterdikleri düşünme biçimini diğer bağlama kolayca aktaramadıkları gösterilmiştir. Bu bağlamda, her seviyeden farkı öğrenci grupları ile kovaryasyonel düşünme becerilerinin mevcut durumu ve geliştirilmesine yönelik benzer çalışmalar yapılabilir. Bu tür çalışmaların artması kovaryasyonel düşünme becerisini açık bir şekilde tanımlamamıza ve dolayısıyla bu beceriyi geliştirmek için daha etkili pedagojik yaklaşımlar geliştirmemize yardımcı olabilir. Örneğin, bu çalışmada da gözlemlendiği gibi cebirsel denklemler oluşturarak düşünen öğrencilerin kovaryasyonel düşünme öğelerini yansıtmamasının ne anlama geldiği (Thompson ve ark., 2017) ve kovaryasyonel düşünme becerisinin niceliksel düşünme gibi diğer becerilerle ilişkisi üzerine çalışmalar yapılabilir. Farklı öğrenci seviyelerinde, öğretmenlerin kullanım yöntemine bağlı olarak matematik derslerinde teknoloji kullanımının kovaryasyonel düşünme becerisini nasıl desteklediği araştırılabilir. Yine oran-orantı, doğrusal denklemler, fonksiyon, türev ve integral gibi bazı kavramların anlaşılmasında kovaryasyonel düşünmenin rolü üzerine daha kapsamlı çalışmalar yapılabilir. Bu konu ve kavramların ders kitaplarında ve müfredat ile ilgili diğer kaynaklarda ele alınış biçimi kovaryasyonel düşünmeye 
vurgu bakımından incelenmelidir. Zira öğretmenlerde, öğretmen adaylarında ve farklı seviyelerden öğrencilerde kovaryasyonel düşünme becerisinin yeterli olmaması, sorunun ilköğretimden itibaren birçok matematiksel kavramın öğretim yaklaşımıyla ilgili olabileceğini göstermektedir.

Ek 1. Su Deposu, Kayan Merdiven ve Uzay Mekiği modelleme etkinlikleri

\section{Su Deposu}

Yanda bir depo şekli görülmektedir. Bu depo sabit debili bir musluk ile doldurulmaktadır. Hacme bağlı olarak yüksekliğin nasıl değiştiğini açılayınız.

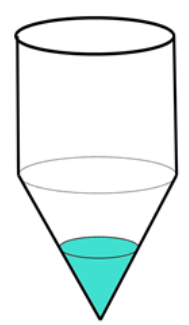

\section{Kayan Merdiven}

Duvara karşı dik pozisyonda duran bir merdivenin uç noktaları şekilde görüldüğü üzere A ve B olsun. Merdiven A noktasından tutularak zemin üzerinde ok yönünde sabit hızla çekilmektedir. Merdiven zemin üzerinde kaydıkça; Merdivenin B noktasının zemine olan uzaklığı ile A noktasının duvara olan uzaklığı birlikte nasıl değişmektedir? Grafiğini de çizerek açıklayınız.

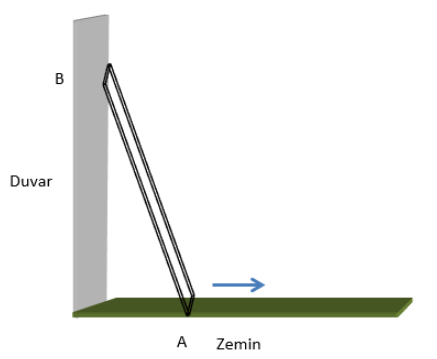

\section{Uzay Mekiği}

Bir uzay mekiğinin uzaya firlatılmasını görüntülemek isteyen bir kameraman kameranın açısını uzay mekiği görüntüden kaybolana kadar sürekli değiştirmek zorundadır. Buna göre kamera açısı $(\alpha)$ ile uzay mekiğinin yerden yüksekliği birlikte nasıl değişmektedir? Grafiğini de çizerek açıklayınız.

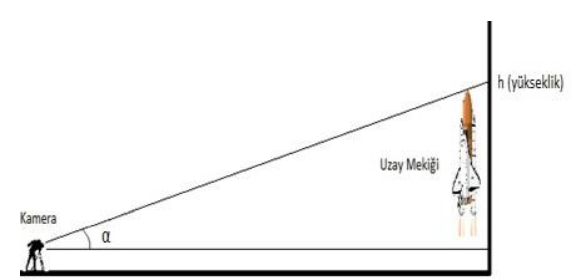

\section{Kaynaklar/References}

Ärlebäck, J. B., Doerr, H. M., \& O’Neil, A. M. (2013). A modeling perspective on interpreting rates of change in context. Mathematical Thinking and Learning, 15(4), 314-336.

Carlson, M. P. (1998). A cross-sectional investigation of the development of the function concept. In A. H. Schoenfeld, J. Kaput, \& E. Dubinsky (Eds.), CBMS Issues in Mathematics Education: Research in Collegiate Mathematics Education III (Vol.7, pp. 114-162). Washington DC: American Mathematical Association.

Carlson, M., Jacobs, S., Coe, E., Larsen, S., \& Hsu, E. (2002). Applying covariational reasoning while modeling dynamic events. Journal for Research in Mathematics Education, 33(5), 352-378.

Carlson, M., Larsen, S., \& Lesh, R. (2003). Integrating a models and modeling perspective with existing research and practice. In R. Lesh, \& H. Doerr (Eds.), Beyond constructivism: Models and modeling perspectives on mathematics problem solving, learning, and teaching (pp. 465-478). Mahwah, NJ: Lawrence Erlbaum Associates.

Castillo-Garsow, C. (2012). Continuous quantitative reasoning. In R. L. Mayes, \& L. Hatfield (Eds.), Quantitative reasoning and mathematical modeling: A driver for STEM integrated education and teaching in context (pp. 55-73). Laramie: University of Wyoming Press.

Confrey, J., \& Smith, E. (1994). Exponential functions, rates of change, and the multiplicative unit. Educational Studies in Mathematics, 26(2/3), 134-165.

De Bock, D., Van Dooren, W., Janssens, D., \& Verschaffel, L. (2002). Improper use of linear reasoning: An indepth study of the nature and the irresistibility of secondary school students' errors. Educational Studies in Mathematics, 50(3), 311-334. 
Donevska-Todorova, A. (2018). Recursive exploration space for concepts in linear algebra. In L. Ball, P. Drijvers, S. Ladel, HS. Siller, M. Tabach, C. Vale (Eds.), Uses of technology in primary and secondary mathematics education. ICME-13 Monographs (pp. 351-361). Cham, Switzerland: Springer International Publishing.

Herbert, S., \& Pierce, R. (2011). What is rate? Does context or representation matter? Mathematics Education Research Journal, 23(4), 455-477.

Herbert, S., \& Pierce, R. (2012). Revealing educationally critical aspects of rate. Educational Studies in Mathematics, 81(1), 85-101.

Hoffkamp, A. (2011). The use of interactive visualizations to foster the understanding of concepts of calculus: Design principles and empirical results. ZDM-Mathematics Education, 43(3), 359-372.

Johnson, H. L. (2012). Reasoning about variation in the intensity of change in covarying quantities involved in rate of change. The Journal of Mathematical Behavior, 31(3), 313-330.

Johnson, H. L., McClintock, E., \& Hornbein, P. (2017). Ferris wheels and filling bottles: A case of a student's transfer of covariational reasoning across tasks with different backgrounds and features. ZDM-Mathematics Education, 49(6), 851-864.

Jones, S. R. (2017). An exploratory study on student understandings of derivatives in real-world, non-kinematics contexts. The Journal of Mathematical Behavior, 45, 95-110.

Keene, K. A. (2007). A characterization of dynamic reasoning: Reasoning with time as parameter. Journal of Mathematical Behavior, 26, 230-246.

Kertil, M. (2014). Pre-service elementary mathematics teachers' understanding of derivative through a model development unit (Unpublished doctoral dissertation). Middle East Technical University, Graduate School of Natural and Applied Sciences, Ankara.

Kertil, M., Erbaş, A. K., \& Çetinkaya, B. (2019). Developing prospective teachers' covariational reasoning through a model development sequence. Mathematical Thinking and Learning, 21, 207-233.

Lesh, R., Hoover, M., Hole, B., Kelly, A., \& Post, T. (2000). Principles for developing thought-revealing activities for students and teachers. In R. Lesh, \& A. Kelly (Eds.), Handbook of research design in mathematics and science education (pp. 591-645). Hillsdale, NJ: Lawrence Erlbaum.

Lobato, J., \& Ellis, A. B. (2010). Developing essential understandings of ratios, proportions, and proportional reasoning for teaching mathematics in grades 6-8. Reston, VA: National Council of Teachers of Mathematics.

Lobato, J., \& Thanheiser, E. (2002). Developing understanding of ratio-as-measure as a foundation for slope. In B. Litwiller, \& G. Bright (Eds.), Making sense of fractions, ratios, and proportions: 2002 yearbook (pp. 162175). Reston, VA: National Council of Teachers of Mathematics.

Monk, S. (1992). Students' understanding of a function given with a physical model. In G. Harel \& E. Dubinsky (Eds.), The concept of function: Aspects of epistemology and pedagogy (pp. 175-193). Washington, DC: Mathematical Association of America.

Oehrtman, M. C., Carlson, M. P., \& Thompson, P. W. (2008). Foundational reasoning abilities that promote coherence in students' understandings of function. In M. P. Carlson, \& C. Rasmussen (Eds.), Making the connection: Research and practice in undergraduate mathematics (pp. 27-42). Washington, DC: Mathematical Association of America.

Saldanha, L., \& Thompson, P. (1998). Re-thinking co-variation from a quantitative perspective: Simultaneous continuous variation. In S. B. Berensen, \& W. N. Coulombe (Eds.), Proceedings of the Twentieth Annual Meeting of the North American Chapter of the International Group for the Psychology of Mathematics Education (pp. 298-304). Raleigh, NC: North Carolina State University.

Stalvey, H. E., \& Vidakovic, D. (2015). Students' reasoning about relationships between variables in a realworld problem. The Journal of Mathematical Behavior, 40, 192-210.

Strauss, A., \& Corbin, J. (1998). Basics of qualitative research: Techniques and procedures for developing grounded theory (2nd ed.). Thousand Oaks, CA: Sage.

Stroup, W. (2002). Understanding qualitative calculus: A structural synthesis of learning research. International Journal of Computers for Mathematical Learning, 7(2), 167-215.

Şen-Zeytun, A., Cetinkaya, B. ve Erbas, A. K. (2010). Matematik öğretmenlerinin kovaryasyonel düşünme düzeyleri ve öğrencilerinin kovaryasyonel düşünme becerilerine ilişkin tahminler. Educational Sciences: Theory and Practice, 10(3), 1601-1612.

Thompson, P. W. (1994). Images of rate and operational understanding of the fundamental theorem of calculus. Educational Studies in Mathematics, 26, 229-274. 
Thompson, P. W. (2011). Quantitative reasoning and mathematical modeling. In L. L. Hatfield, S. Chamberlain, \& S. Belbase (Eds.), New perspectives and directions for collaborative research in mathematics education (Vol. 1, pp. 33-57). Laramie, WY: University of Wyoming.

Thompson, P. W., \& Carlson, M. P. (2017). Variation, covariation, and functions: Foundational ways of thinking mathematically. In J. Cai (Ed.), Compendium for research in mathematics education (pp. 421-456). Reston, VA: National Council of Teachers of Mathematics.

Thompson, P. W., Hatfield, N. J., Yoon, H., Joshua, S., \& Byerley, C. (2017). Covariational reasoning among U.S. and South Korean secondary mathematics teachers. The Journal of Mathematical Behavior, 48, 95-111.

Yemen-Karpuzcu, S.,Ulusoy, F., Işıksal- Bostan, M. (2017). Prospective middle school mathematics teachers' covariational reasoning for interpreting dynamic events during peer interactions. International Journal of Science and Mathematics Education, 15, 89-108.

Yıldırım, A. ve Şimşek, H. (2011). Sosyal bilimlerde nitel araştırma yöntemleri. Ankara: Seçkin Yayıncılık.

Zbiek, R. M., Heid, M. K., Blume, G. W., \& Dick, T. P. (2007). Research on technology in mathematics education: The perspective of constructs. In F. Lester (Ed.), Handbook of research on mathematics teaching and learning (Vol. 2, pp. 1169-1207). Charlotte, NC: Information Age Publishing. 